\title{
Gentrification on the Planetary Urban Frontier: The Evolution of Turner's Noösphere
}

\section{Elvin Wyly}

Abstract: As capitalist urbanization evolves, so too does gentrification. Theories and experiences that have anchored the reference points of gentrification in the Global North for half a century are now rapidly evolving into more cosmopolitan, dynamic world urban systems of variegated gentrifications. These trends seem to promise a long-overdue postcolonial provincialization of the entrenched Global North bias of urban theory. Yet there is a jarring paradox between the material realities of some of the largest non-military urban displacements in human history in the Global South, alongside a growing reluctance to 'impose' Northern languages, theories, and politics of gentrification to understand these processes. In this paper, I negotiate this paradox through an engagement of several seemingly unrelated empirical trends and theoretical debates in urban studies and gentrification. My central argument is that interdependent yet partially autonomous developments in urban entrepreneurialism and transnational markets in labor, real estate, and education are transcending the dichotomy between gentrification in cities (the traditional focus of so much place-based research) versus gentrification as a dimension of planetary urbanization. Amidst the planetary technological transformations now celebrated as "cognitive capitalism" and a communications-consciousness “noösphere," these developments are coalescing into a global, cosmopolitan, and multicultural tapestry of explicitly evolutionary class transformations of urban space that adapt to multiplyscaled contingencies of urban history, socio-cultural difference, state power, and terrains of resistance. The argument proceeds in three steps. First, I explain how social Darwinism was deeply embedded within conventional urban theory in the decades before Ruth Glass gave us a language for the discussion of gentrification, thus perpetuating debates over narrow empirical 
issues at the expense of deeper critical scrutiny of the evolutionary logics of socio-spatial classifications. Second, I examine the recent movement for a "cosmopolitan decolonization" of gentrification theory that has emerged at the precise moment when powerful alliances are consolidating the networked infrastructures of gentrification on an unprecedented scale. Third, I analyze the contemporary evolution of gentrification as a recombinant blend of old and new, as the means of class transformation of urban space are accelerated through intensified competition in work, education, and housing. The built environments of planetary urbanization provide ample opportunities not only for diverse cosmopolitan descendants of old-fashioned urban renewal in the style of Haussmann's Paris or Moses' New York, but also for new generations of 'capitalists with conscience' -- entrepreneurial coalitions closing 'moral rent gaps' by integrating the economic profits of gentrification with the discourses and practices of environmental sustainability, socially responsible development, and global fields of educational opportunity. All of these escalating competitions are legitimated as inclusive multicultural meritocracies. Yet the relentless optimism of competitive innovation in the cognitive-capitalist noösphere is creating dangerous new frontiers of human ecology that reproduce the social-Darwinist "form of society" that Frederick Jackson Turner envisioned in his theorization of the "recurrence of the process of evolution" in America's colonial-settler waves of violent dispossession. [Key words: gentrification, noösphere, social Darwinism, Chicago School.] 


\section{Sexton's New Frontier}

"With the sum total of human knowledge, past and present, at our fingertips," we're told on the website Big Think (2014), “we're faced with a crisis of attention: which ideas should we engage with, and why?" Big Think promises to help us sift through this vast informational rainforest, offering "an evolving roadmap to the best thinking on the planet," so we can appreciate and use the important concepts that can be "lenses for envisioning the future." John Sexton, the charismatic and polarizing "imperial President” (Aviv, 2013) of New York University, has seen that future, and in a Big Think video (Sexton, 2008) he offers an appropriately audacious thought on what it all means. "Biodiversity is good," he emphasizes, challenging the obsolete American melting-pot ideology that tried to turn America "into some great Velveeta cheese of humanity." No, Sexton warns, this kind of assimilationist logic is wrong and dangerous. Now, "postenvironmental movement," we now know that biodiversity is good, and "Human diversity is good. Intellectual diversity is good. This is a wonderful gift from God. We don't want to homogenize. We want to create communities of microcommunities. New York is the first experiment in what the whole world is going to be." Sexton's vision for NYU is an institution in and of the city, "ecosystemic in the city," that will demonstrate through its community of microcommunities how "humanity begins to operate like a great watch of interconnecting parts, not isolated from each other, but a whole that's greater than the sum of the parts."

For those who remember the history of urban theory, Sexton's "ecosystemic" metaphors immediately remind us of the dominant Chicago School human ecology tradition of the twentieth century, where the city "is a product of nature, and particularly of human nature," (Park, 1925, p. 
1), with biological metaphors for neighborhood change as 'invasion and succession,' as each social group develops in its own distinctive "natural area" of the city. The bio-logical genealogy of the Chicago School is certainly important for any understanding of the significance of Sexton's project, but his direct inspiration comes from a more surprising, obscure source:

"I have a doctorate in religion, trained by the Jesuits, so I tend to think in Teilhardian terms about a kind of noösphere, where there's a whole different way of existence for humankind...”

Pierre Teilhard de Chardin (1881-1955) was an evolutionary vertebrate paleontologist who was also an ordained Jesuit priest: his life's work became a philosophical synthesis of the science of human evolution with the faith of Catholic theology. He was a prolific writer, but some of his most important works only appeared posthumously, thanks to the Church's prohibition on his challenges to official doctrine. The concept that captures Sexton's imagination comes from the Greek noos (mind) + sphaera (sphere), which Teilhard de Chardin developed through conversations in Paris in the 1920s with the French philosopher Edouard le Roy and the Russian geochemist-cosmologist Vladimir Vernadsky (Turner, 2005). Surveying the spreading environmental consequences of urbanization and industrialization, Vernadsky foresaw a collective human understanding of the need to live as part of, rather than against, nature in all of Earth's "terrestrial zone containing life." (Teilhard de Chardin, 1947, reprinted in Teilhard de Chardin, 1964, p. 151). Teilhard de Chardin refined the noösphere into the idea of a planetary "superstage of consciousness," a "process of co-cerebration" and "co-reflexive evolution" in an irresistible inflexion from complex divergence towards a move that is "compressional and 
converging," driven "by the double curvature of our rounded mother-planet and of our converging minds" (Teilhard de Chardin, 1956, p. 109, 112, 111). Put simply, the expansion of travel, communication, and human interaction to the planetary scale would allow -- through "our converging minds" -- an entirely new phase of the collective evolution of humanity. Humanity would "move toward unheard-of and unimaginable degrees of organized complexity and of reflective consciousness," to become "ultra-reflexive (that is, 'ultra-human')" along the way to an "implosive concentration" of the "cultural noösphere" of earth and every other "thinking planet" in what de Chardin acknowledged was a "wild hypothesis of a transhuman universe" (de Chardin, 1956, p. 111). Teilhard de Chardin's noösphere combined the state of the art in biology and paleontology to fuse "the rise of self-evolution" of an "unbroken sheet of organized consciousness" (Teilhard de Chardin, 1956, p. 109) with Christian theology in a universalizing cosmological ontology of humanity, nature, science, communication, culture, and God. The "Last Page of the Journal of Pierre Teilhard de Chardin," written on Maundy Thursday in 1955 three days before his death, presents a concise diagram of "What I believe," and connects "Christogenesis" to an evolutionary cosmology:

\footnotetext{
“Cosmos $=$ Cosmogenesis -- Biogenesis -- Noogenesis -The universe is centered -- Evolutively..."
}

(Teilhard de Chardin, 1955, in Teilhard de Chardin, 1964, p. 311)

This equation appears under the notes "St. Paul -- the three verses: En pase panta Theos." This is Greek for "God All in All," the culmination of 1 Corinthians (26-28), written by the Apostle Paul in $55 \mathrm{CE}$ in an attempt to unify a fractious church begun only three years earlier in Corinth, 
Greece's thriving, cosmopolitan world city of the day -- with its synagogue and its raucous temples to Apollo and Aphrodite. Teilhard de Chardin died in the Corinth of the American Century, New York City, at the height of an imperial modernity shaped by a collective imagined community built on histories of a West descended from the Greek polis. Images and narratives of these collective memories of the present were suddenly flooding the expanding planetary circuits of the electronic age -- and Teilhard died in 'almost famous' obscurity, even as technological communications breakthroughs were vindicating his claim that "the axis of twentieth-century social evolution lay in the psychic (interpersonal) and political realm" (Buttimer, 1971, p. 85). In an oral history in the 1990s, Tom Wolfe recalls that Marshall McLuhan was "deeply influenced" by Teilhard de Chardin, but McLuhan "never" acknowledged the connection to avoid offending the Catholic hierarchy at his professional home, St. Michael's College at the University of Toronto (see Cavell, 2002, p. 256). But now, in the twenty-first century, the Teilhardian medium is the message, in a 'superstage of consciousness' achieved through planetary communication circuits of entertainment, advertising, marketing, investment, and education in a multipolar world of diverse, dynamic global cities. The noösphere has been the buzzword, the next new thing in Silicon Valley for more than a decade (Lanier, 2010, 2013), and there is now a thriving literature analyzing how globalization and technological change have given rise to a new kind of "cognitive-cultural capitalism" (Moulier-Boutang, 2012; Scott, 2007, 2011a, 2011b, 2014) -- a “"knowledge-based' capitalism” with "biomedical and genetic engineering and artificial intelligence at the forefront" (Harvey, 2014, p. xii). Sexton's (2008) contribution to these discussions involves "glocalizing" NYU's ecosystemic heritage: "we take being in that local city and we extrapolate it out to the world." Sexton's noösphere is what he calls the Global Network University: students are admitted to NYU through one of three 
gateways -- NYU New York, NYU Shanghai, or NYU Abu Dhabi -- and then spend parts of their degree program circulating amongst a world urban system of "idea capitals" including Accra, Berlin, Buenos Aires, Florence, London, Madrid, Paris, Prague, Sydney, Tel Aviv, and Washington, DC. Sexton is explicit in moving beyond the "Eurocentric bias" of existing Ivy League Study Abroad programs, and the goal is "at least 16 sites" in world idea capitals, "with at least one on each of the six inhabited continents." (Sexton, 2010).

Sexton's purpose is to mobilize educational institutions in the world's "glocal cities" to demonstrate the power and possibilities of collective human understanding through diversity -as an emancipatory alternative to the "fortress mentality" of gating strategies that are destined for global catastrophe in rising fears and tensions, "culminating in a "clash of civilizations"” (Sexton, 2010). The noösphere, in other words, offers "a tremendous opportunity in the process of global evolution" (Sexton, 2010). A university "in and of the city," Sexton shows us, can teach us how to nurture what Kwame Anthony Appiah (1997) calls "cosmopolitan patriots" -- "men and women whose interests, vision, and allegiance are not bounded by place or sovereignty and who are 'citizens of the world' as well as of their particular cultures" (Sexton, 2010). While the phrase carries a whiff of elitism, 'cosmopolitan patriots' embody an elitism of meritocratic achievement that moves beyond the narrow nationalist patriotism of the nineteenth and twentieth centuries -- with a fresh transnational outlook that signals the possibility of a benign, empathetic, and responsible collective force for progressive change. The world's best students will come to learn with -- and transform -- NYU's world-class faculty in "kaleidoscopic interaction with deep connectivity," as humanity learns how to produce future generations of "citizens of global society." This is among the world's most selective classes: of the more than 9,000 who applied 
for the inaugural class, NYU Abu Dhabi admitted only 188, representing 39 countries and 43 different languages. ${ }^{1}$

Sexton draws inspiration from cosmopolitan patriots as today's planetary pioneers. ${ }^{2}$ They have the competitive drive and individual ambition signified by Richard Florida's $(2003,2006)$ "creative class," but their diverse and hybrid educational trajectories give them a transnationally refined version of the political progressivism associated with the "new middle class" remaking of city life (Ley, 1996), and they also understand what it means to think and act within collective assemblages of the human and non-human -- creative human beings circulating in a system that he describes as "connected skeletally by highly sophisticated" "social networking technology." To see where the cosmopolitan patriots are going, Sexton borrows from a borrowed metaphor of Prime Minister Gordon Brown:

"To adapt an aphorism coined by President Kennedy, the new frontier is that there is no frontier: no frontier for the internet, for the mobile phone, for e-mails, for the cyber-world; no frontier for the capacity of individuals to influence, inform, or even infuriate each other."

(quoted in Sexton, 2010).

\footnotetext{
${ }^{1}$ Sexton's vision for cosmopolitan patriots and citizens of global society also includes superstar faculty recruitment. NYU Abu Dhabi has led to "an extraordinary elevation of brand," he explains to a correspondent from The Economist; "For 15 years I had been trying to get Anthony Appiah to come to NYU. One Trip to Abu Dhabi, and he came." (Duncan, 2015, p. 11).

${ }^{2}$ Appiah (1997, p. 617) begins his essay thus: "My father was a Ghanaian patriot. He once published a column in the Pioneer, our local newspaper in Kumasi, under the headline, 'Is Ghana Worth Dying For?' and I know that his heart's answer was yes. ..." But when his father died, Appiah and his sisters found an unfinished note of "last words and wisdom" for his children, including this advice: "Remember that you are citizens of the world." (Appiah, 1997, p. 618).
} 
Frontier. Consider three dictionary definitions: "the border separating one country from another," "an area of mental activity where much remains to be done," and "a marginal region between settled and unsettled lands." (Cayne, 1990, p. 382). This is where John Sexton's Big Think, Gordon Brown's New Frontier, and Pierre Teilhard de Chardin's noösphere help us understand the frontiers of gentrification today -- more than half a century after Ruth Glass (1964) first gave us a word to describe this process of urban transformation. In The New Urban Frontier, Neil Smith (1996) analyzed how the genocidal disposessions of Frederick Jackson Turner's understanding of the frontier in eighteenth- and nineteenth-century America -- "the meeting point between savagery and civilization" (Turner, 1893, p. 200) -- became the powerful discourses and material realities of developers "circling the wagons" to retake Harlem and all the other territories lost in America's twentieth-century urban crisis. In "Gentrification as Global Urban Strategy," Smith (2002) diagnosed how these frontier processes were being consolidated through transnational urban systems of entrepreneurial capitalist-state coalitions mobilizing city spaces as vehicles for speculative real-estate accumulation. And in one of his last written works, “The Evolution of Gentrification," Smith (2011) diagnosed the accelerating pace of dispossession as cosmopolitan capital operated through transnational network architectures of revanchist uneven development on a planetary scale.

Yet there is a tantalizing absence in Smith's use of the word evolution. While he diagnoses "an extraordinary new departure" in the scale of today's "economic excommunication of workingclass people from their communities," Smith is uncharacteristically cautious and modest in this essay, and never pushes the meaning of 'evolution' beyond the familiar, neutral sense of change or transformation. We can learn a great deal if we take Smith's title literally, to be bold and 
explicit on the evolutionary dynamics of gentrification. Part of my inspiration here comes from Eric Clark (1987), who undertook a meticulous examination of centuries of land records in order to build an empirical foundation for Smith's (1979) theory of the rent gap in the dynamics of urban transformation; more recently, analyzing the unprecedented challenge of "collective selfregulation" of planetary humanity that will be required if we are to achieve sustainability, Clark has documented the distortions of evolutionary science that have privileged "gene-centered thought" and an "excessive individualism" that obscures Darwin's perspective on species participating collectively in their own development (Clark and Clark, 2012, p. 563). In this paper, my goal is to extend this line of inquiry, focusing more explicitly on the matter of evolution in frontier metaphors in urban theory, and in the driving ambitions of cosmopolitan patriots and their visionary mentors like John Sexton. My central claim is that we are living through a planetary software update of nineteenth-century, Turneresque social Darwinism -creating a bizarre transnational urbanization of Chicago School positivist logics masked by the deceptive drop-down-menu multiculturalism of Silicon Valley's automated postpositivist standpoint epistemologies. The noösphere is the new frontier of gentrification as the new urban colonialism (Atkinson and Bridge, 2005) of today's planetary cognitive capitalism. We are challenged to reconsider the explicit and implicit political ethics of the "recurrence of the process of evolution" in the "process of expansion" of this new frontier (Turner, 1893, p. 200).

Let me tell this story in three parts. First, we'll consider the role of evolution in the historical context of conventional urban theory before Ruth Glass gave us a discourse for the analysis of gentrification. The key point here is that fundamental axioms of a hijacked social Darwinism accomplished a stealth corruption of mainstream urban theory, necessitating the aggressive 
political edge that came to define the very best of gentrification scholarship; unfortunately, gentrification theory was shaped by reactions to specific and partial aspects of the Chicago School's legacy -- perpetuating debates over narrow empirical issues, and distracting attention from the evolutionary frontier ontology that is much more relevant for an understanding of the cognitive-capitalist noösphere under conditions of planetary urbanization. Second, we'll consider a recent political paradox that has emerged with the arrival of planetary urbanization: influential, well-intentioned calls for cosmopolitan perspectives from beyond the "core" of the Global North are being voiced at the precise moment when powerful coalitions are consolidating the networked infrastructures of gentrification on an unprecedented planetary scale. Third, I'll evaluate the way this latest era of gentrification is a recombinant blend of old and new, with intensified class competition in education, labor, and housing markets legitimated on the basis of harsh nineteenth-century evolutionary frontier philosophies masquerading as inclusive multicultural meritocracies. Special scrutiny is here reserved for the bizarre technological theologies enacted in and through Silicon Valley -- a location that only begins in the San Francisco Bay Area. The "non-place urban realm" of "community without propinquity" diagnosed by the Berkeley urban theorist Melvin Webber (1964) has been thoroughly transnationalized, as the "massive communication systems" (p. 86) of urbanism are now enmeshed in planetary networks of finance, information, and production sweatshops -- all interconnected through billions of smartphones that promise the wealth of accumulated human knowledge at the swipe of a thumb. The possibilities seem infinite. But Silicon Valley's noösphere is creating dangerous new frontiers of Turner's evolutionary encounters between "savagery and civilization." 


\section{The Urbanization of Evolutionary Consciousness}

The first part of our story involves the way social Darwinism was encoded into the twentiethcentury hegemony of urban theory that conditioned public policy, capital investment, and social analysis in the generations before Ruth Glass (1964, p. xviii) first wrote the word "gentrification." As industrialization transformed political economy at the beginning of the nineteenth century and produced the world's first urbanized nation at century's end, evolutionary perspectives on urban life were quite explicit. In Cities in Evolution, Patrick Geddes (1915) portrayed the day's emergent, large, polycentric city-regions -- what he called "conurbations" -as the logical evolution of previous kinds of cities, in a new industrial revolution. For Geddes, the old "paleotechnic" industrial age dominated by obsessions with individual wealth and class division was evolving, through urbanization, to a "neo-technic order" of collective, civic wealth, “its skill directed by life towards life, and for life ...." Humanity would set its mind "towards house-building and town-planning, even towards city design; and all these upon a scale to rival -nay, surpass -- the past glories of history." (Geddes, 1915, p. 71).

Robert Ezra Park was similarly explicit when he was strengthening the foundations of a department of sociology at the University of Chicago that would eventually come to be known as “Urbanism, Incorporated” (Martindale, 1958, p. 28). Park’s (1921) theoretical justification for the young discipline -- “the science of collective behavior" (p. 21) -- combined Durkheim's theories of organic solidarity with the social philosophies of the nineteenth century physical scientists who had made sociology possible. Auguste Comte's (1842) ontology of "social physics" offered a scientific, post-theistic positivist theory of cumulative, intergenerational 
advancement in the "Great Being" of humanity, while Herbert Spencer's grand synthesis of biology and physics provided a framework for the progress of industrial modernity and the development of what he had called as early as 1860 the "social organism." In turning to Spencer, Park was channeling the evolutionary theorist with the deepest influence on the American mind in the last half of the nineteenth century. "Mr. Herbert Spencer is already a power in the world," the Atlantic Monthly enthused in 1864; "As far as the frontiers of knowledge where the intellect may go, there is no living man whose guidance may more safely be trusted. Mr. Spencer represents the scientific spirit of the age" (Atlantic Monthly, 1864, p. $775,776)$. Yet that spirit was a chaotic conception of revolutionary advances in science mangled with the entrenched conservatism of economics and religion. Spencer's "doctrine of the Unknowable" provided an overriding concession that gave theologians a credible, face-saving reconciliation of creationism and evolution (albeit an obsolete Lamarckian version) while his insistence on the absolute freedom of private enterprise made him the philosopher of choice for America's dominant capitalists. In a Sunday-school speech, John D. Rockefeller cited Spencer's catch-phrase "the survival of the fittest' to justify the "law of nature" and "the law of God" in the growth of the era's powerful industrial and financial trusts (cited in Ghent, 1902, p. 29). But if Park's (1921) theorization of the "collective mind" and the "social consciousness" was influenced by Spencer's linear laissez-faire evolution -- Spencer was, after all, a major influence on Albion W. Small, the sociologist who hired Park at Chicago -- there were other, more progressive influences at work. Long before he came to Chicago Sociology, Park took a lowpaid research assistant position after completing his doctorate in order to work at Harvard with the pragmatist philosopher William James. Earlier still, as an undergraduate at the University of Michigan between 1883 and 1887, Park had been deeply shaped by the teaching of a newly- 
arrived Ph.D. from Johns Hopkins -- John Dewey. Of the ten courses Park took in the philosophy department, six were with Dewey.

Dewey fundamentally transformed Spencer's self-rationalizing apologies for structured social inequalities -- what Dewey (1920, p. 190) called "the apparatus for intellectual justification of the established order." Whereas Spencer's logic portrayed individual competition and selection in a fixed environment, Dewey realized that Spencer misunderstood Darwin: cooperation matters as well as competition, and the environment is changed by human actions -- which change over the generations as human knowledge and tradition evolve. ${ }^{3}$ Born in the year Darwin's Origin of Species was published, Dewey in later years wrote that the book not only "marked an epoch in the development of the natural sciences," but also revolutionized nearly all of the "conceptions that had become the furniture of the mind" over two thousand years, transforming "the logic of knowledge" across the expanding terrain of the social sciences "and hence the treatment of morals, politics, and religion" (Dewey, 1909, p. 90). In America, however, these ideas had been distorted by the brutal orthodoxy of the "laissez-faire conservatives" (Hofstadter, 1944) -- the hardcore Cro-Magnons whose extreme positions were too much even for Richard Ely, the conservative economist who helped fuse "environment, evolution, and cartography" by getting Frederick Jackson Turner so interested in maps when Turner was pursuing an otherwise classical, non-geographical history curriculum at Johns Hopkins (Block, 1980, p. 32). Ely (1884, p. 64) became concerned that evolutionary theory was

\footnotetext{
${ }^{3}$ Indeed, part of Dewey's brilliance was in applying evolutionary logics to individual theories and theorists themselves. Dewey saw Spencer's enormous popularity in laissez-faire America as the historically evolutionary culmination of English liberalism: "he is not one creator with many others of the theory of evolution, but its own concrete incarnation" (Dewey, 1904, p. 53).
} 
being abused "as an excuse for doing nothing while people starve," citing the "all-sufficiency of competition as a plea for grinding the poor."

Dewey brought together Comte's insights on the intergenerational collective of knowledge (what Marx once called the 'general intellect') with Darwinian evolution. It is not just bodies and physical characteristics that evolve; knowledge, understanding, methods of communication, social and cultural institutions, and human possibility evolve too. And we can decide how to participate in our evolution. In the same way Spencer's dogmatic commitment to an atomized individualism had provided a fraudulent justification for laissez-faire, "our ingrained habit of regarding intelligence as an individual possession" (Dewey, 1939, p. 456) had thwarted the progressive possibilities of education and politics. "Intelligence is a social asset," Dewey (1939, p. 456) emphasized, "with a function as public as its origin, in the concrete, in social coöperation." There was no need to remain trapped by the retrograde conservatism of Spencerian Social Darwinism, of "drifting," waiting "for the slow process of evolution" as the "working out of unconscious, natural law" (Dewey, 1918, quoted in Dewey, 1939, p. 424). Cooperation and the development of the collective societal wealth of knowledge make us active, conscious participants in our relations with one another and with the social and natural environments in which we build and share knowledge. "It is proved now," Dewey wrote, "that it is possible for human beings to take hold of human affairs and manage them, to see an end which has to be gained, a purpose which must be fulfilled, and deliberately and intelligently go to work to organize the means, the resources, and the methods of accomplishing those results" (Dewey, 1918, quoted in Dewey, 1939, p. 424). Evolution is a collective, social process that proceeds through cooperation and communication -- social relations that were concentrating and 
accelerating with urbanization. The "untranscendental pragmatist" Dewey and the "empirical sociologist" Park became America's most perceptive analysts of how cooperative, communicative evolution was urbanizing (White and White, 1962, p. 155).

This is where we encounter a fascinating yet forgotten moment in our inherited memories of urban studies. Viewed as a distant historical reference point, Chicago School urbanism is today understood as a vanquished but unrepentent hegemony, as a "bourgeois social science" so dominant that Harvey $(1978$, p. 68$)$ once likened a debate request to "an invitation to the sheep to come sit down and parley with the wolves." The ossified dogmatic paradigm Harvey encountered in the last quarter of the twentieth century was a betrayal of the progressive possibilities of the first. The most crucial potential emerges from the fascination that Dewey, Park, and the first generation of Chicago School sociologists had for the central role of communications technologies in accelerating the circulation of information and meaning in urban society -- a circulation process that was constantly altering the very constitution of 'society' and thus producing new social environments for the collective process of evolution of the next generation. "Park espoused a cognitive Darwinism," J. Nicholas Entrikin (1980, p. 47) writes in a landmark history of human ecology, "in which knowledge evolved and expanded in order to meet the needs created by new problems" faced by humanity. "Cognitive Darwinism" might strike you as a bizarre, slightly troubling phrase: Darwinian evolution requires death to achieve progress, and 'cognitive' means that you're now thinking about what it means for that progress to involve your death. I certainly did a double-take, and thought of my own mortality, when I first saw the phrase in Entrikin's brilliant historiography of a figure so central to Chicago School urban theory. The phrase has been forgotten, with only a few exceptions (e.g., Rescher, 
1977, 2005), ${ }^{4}$ because evolutionary urbanism developed a politicized amnesia. Especially in America, evolutionary social theory began to avoid explicit references to Spencer, Darwin, or any other clearly-recognized biological framework. Park's work at Chicago building a new urban theory took place in the era of the Scopes Trial, and the violence of the 'War to End All Wars' had discredited the influential racist and imperialist perversions of Darwinism that had made so much of European civilization and Teutonic superiority. Likewise for the eugenics movement that flourished from the turn of the century, which "grew with such great rapidity that by 1915 it had reached the dimensions of a fad," when notions of the preservation of the "racial stock' as a "means of national salvation" fostered support for the geopolitical theories of “evolutionary human geography” led by "militant nationalists" like Theodore Roosevelt and his geographer, Isaiah Bowman -- who, not incidentally, declared that Turner's death in 1932 was “a loss no less severe to American geography than to the study of American history" (Bowman, 1932, p. 499; cf. Hofstadter, 1944, p. 161, 163-164; Smith, 2003, p. 223). The eugenics movement became politically toxic as the Nazis pursued its logic in a refined science of genocide. In this environment, "[m]ention of Darwinism in the social sciences became highly unfashionable” (Hodgson, 2009, p. xix).

Despite (or perhaps because of) this hostile environment, evolutionary logics quickly mutated in ways that made them ever more central to mainstream theories of change in economy, society, and urbanism. The paradox was most pronounced in economics. The Darwinian epistemologies

\footnotetext{
4 "The concept of knowledge as a tool for survival -- cognitive Darwinism -- is as old as biological Darwinism," Rescher (1977, p. 126) emphasizes. Rescher's (1977) "evolutionary epistemology" places cognitive Darwinism at the center of pragmatism much as Harvey (2011) places "mental conceptions of the world" at the core of his contemporary understanding of a "coevolutionary" historical materialism. Rescher (1977, p. 307) makes the case that "European Marxists" and "American pragmatists" share the fundamental "tendency of thought -- the idea of the controlling role of the demands of practical life as the ultimate arbiter of cognitive adequacy." Rescher's (2005, $p$. $\mathrm{x}$ ) subsequent inquiry has focused on a critical realist pragmatism devoted to "how we can manage our cognitive affairs sensibly in situations of imperfect information."
} 
of Milton Friedman's (1953, p. 22) portrayal of the maximization-of-returns hypothesis of firm survival in terms of "natural selection" and Thorstein Veblen's proposal for a reconstruction of economics as a "post-Darwinian" science were downplayed in favor of the technocratic, neutral discourses that were coming to define American logical positivism (Hodgson, 2003a; Mirowski, 2005). ${ }^{5}$ The institutional and evolutionary economist Geoffrey Hodgson (2003, p. 93) notes that as late as the establishment of the Association for Evolutionary Economics in 1966, the label 'evolutionary' was adopted "only by ridding it of any of its former and Veblenian connections with Darwinism and by interpreting it in the broad and banal sense of 'change." And yet Darwinism had always been a "derivative of political economy," (Hofstadter, 1944, p. 38) what Donald MacKenzie (1976, p. 503) calls "the biological variant of political economy." Darwin struggled for more than a year after his expeditions on the Beagle trying to make sense of his samples and empirical observations, but it was only after he read a book on the political economy of population that he "at last got a theory by which to work." The theory that Darwin finally got -- Malthus's 1798 Essay on the Principle of Population -- had become one of the definitive manifestos of the nineteenth century. Darwin was reading the sixth edition, published

\footnotetext{
${ }^{5}$ Friedman's appeal to "natural selection" had an "enduring influence" in the field's hegemony, but the early postwar "brief flurry" of "biological thinking in economics had less impact than its successors. Its much diminished effect is explicable, given its immediacy after the Nazi holocaust, and the prior reaction against biological thinking in the social sciences in the 1920s and 1930s" (Hodgson, 2009, p. xxi). In a foreshadowing of the dog-whistle discourses that would later become so effective in the ruthless politics of neoliberalism, Friedman (1953, p. 22) includes scare quotes in his brief engagement with evolutionary theory: "The process of 'natural selection' thus helps to validate the hypothesis -- or, rather, given natural selection, acceptance of the hypothesis can be based largely on the judgment that it summarizes appropriately the conditions for survival." Friedman (1953) manages to cite Veblen as well as Armen Alchian's (1950) famous and explicitly Darwinian analysis of uncertainty without ever once mentioning 'Darwin' or 'evolution' in the text or the index.

${ }^{6}$ When Darwin's "first note-book was opened," he "worked on true Baconian principles \& without any theory collected facts on a wholesale scale," but "how selection could be applied to organisms living in a state of nature remained for some time a mystery to me. In October 1838, that is fifteen months after I had begun my systematic enquiry, I happened to read for amusement 'Malthus on Population', \& being well prepared to appreciate the struggle for existence which everywhere goes on from long-continued observation of the habits of animals \& plants, it at once struck me that under these circumstances variations would tend to be preserved $\&$ unfavorable ones to be destroyed. The result of this would be the formation of new species. Here then I had at last got a theory by which to work;" (Darwin, 1876, p. 410, 411).
} 
in 1826 (Secord, 2008, p. xix), and it helped break his writer's block as he worked out the details of his theory -- until the discovery that the naturalist Alfred Russel Wallace was pursuing the same line of inquiry led to a simultaneous announcement at the 1858 meeting of the Linnaean Society in London. "Since it had been one of the great figures of the classical economic tradition who had led Spencer, Darwin, and Wallace toward their evolutionary theories," the historian Richard Hofstadter (1944, p. 144) observes, "the economists might have had some justification for proclaiming that biology had merely universalized a truth that had been in their possession for a long time." The core of economics had always privileged laissez-faire competition as a "doctrine of social selection," (Hofstadter, 1944, p. 144) and Keynes (1926, p. 113) went so far as to declare that "the principle of the Survival of the Fittest could be regarded as one vast generalization of the Ricardian economics."

From the 1940s through the 1960s during the period Hodgson (2009, p. xix) labels "The Dark Age of Darwinism in Economics," the field's foundational implicit social Darwinism conditioned the development of conventional urban theory, as neoclassical economic methodology was enmeshed with Chicago sociology frameworks for analyzing neighborhoods, cities, and metropolitan regions. Classical economics and social Darwinism were both founded on an axiomatic trinity: 1) "the fundamentally self-interested animal" maximizing utility (survival), 2) the normality and universality of competition, and 3) the survival of the organism / producer / worker most efficiently adapted to its environment. Yet while "both classical economics and natural selection were doctrines of natural law" (Hofstadter, 1944, p. 145), the twentieth-century consolidation of econometrics created an entirely new infrastructure in which social Darwinist processes could be embedded in the technocratically scientific and presumptively neutral, 
objective mechanisms of simultaneous equations, general and partial equilibrium solutions, and marginal productivity estimates as applied to the exploding observational vistas of economic data. The methodological genealogy goes all the way down, to a literally embodied Darwinian lineage: we wouldn't have the correlation coefficient if Darwin's cousin, the eugenicist Francis Galton and author of Hereditary Genius (1869) hadn't been so obsessed with the 'Gaussian Law of Error' describing the variations around the averages of physical measures of human bodies (biometrics) and the "mental peculiarities of different races" (p. v); those variations around the mean "could be made the source of intellectual progress: specifically for Galton's purposes geniuses could be made" (Barnes, 1998, p. 213). And in turn we wouldn't have chi-square or regression if Karl Pearson hadn't been so anxious to “provide his particular form of Darwinism with a proper scientific basis" (Norton, 1978, p. 6) and if he hadn't been inspired in 1890 to focus on statistics after meeting a zoology professor, Walter Weldon, who was infusing Galton's ideas into evolutionary biology to create a "mathematical theory of evolution" (Norton, 1978, p. 6). When Galton died, his financial remains allowed Pearson to become the first Galton Professor of Eugenics at University College, London, and to merge the two labs he directed -the Biometric Laboratory and the Galton Laboratory for National Eugenics -- into the Department of Applied Statistics. The Galton legacy of correlation and the dismal-science moralism of Malthus that inspired Darwin almost crossed paths with the noösphere and urban studies at the international symposium in Princeton, New Jersey in 1955 ("Man's Role in Changing the Face of the Earth") where Father Teilhard was scheduled to present his paper, "The Antiquity and World Expansion of Human Culture" (de Chardin, 1956). Teilhard didn't make it, but Patrick Geddes' American acolyte Lewis Mumford did, and so did Sir Charles Galton Darwin (grandson of the Darwin), delivering a neomalthusian warning on "the menace of world 
overpopulation" and outlining a "rather fanciful exaggeration" in the form of a scenario of a "genetic surgeon" working to improve humanity by distilling all of the accumulated knowledge of the chromosomes of humanity "to produce an embryo which will develop into" a "really great man": "Shakespeare, Newton, Napoleon, or -- let us be broadminded, since we cannot foresee the political tastes of the surgeon -- perhaps Marx." (Darwin, 1956, p. 965). ${ }^{7}$

To be sure, this discussion takes us a long way from the familiar debates of the gentrification literatures. But this context was crucial in shaping urban social theory at a pivotal moment, when vivid memories of the environmental determinism of Turner's day (see Block, 1980) jostled awkwardly with a new evolutionary mainstream from economics, mathematics, and physics (Berry, 1978, 1980) and the aspirations of the social sciences' quantitative revolutions. In the industrialized urbanism of America, these tensions could be resolved through the implicitly Darwinian economics of "applied statistics" and the "imperial conquests of the rational actor model" (Hodgson, 2003b, p. x) fused with Chicago School human ecology -- yielding a comprehensive and internally consistent matrix of policy-relevant theory. Housing filtering metaphors emphasized households' adaptive responses to the changing landscape of old and new homes in the expanding metropolis (Lowry, 1960). Neighborhood "life cycle" theories naturalized the hierarchical processes of 'upward' status mobility via suburbanization, and 'downward' spirals of decline with racial transition in the inner city (Metzger, 2000). The

\footnotetext{
${ }^{7}$ The "mathematical theory of evolution" of Galton, Weldon, and Pearson intersected (or nearly so) in Princeton in other ways. Charles Galton Darwin directed the U.K.'s National Physical Laboratory in the years Alan Turing developed the analysis culminating in a 1948 research report on Intelligent Machinery, and Darwin arrived for the Man's Role conference during the months when the Williams vacuum tube amplifiers of the new computer at the nearby Institute for Advanced Study were working the night shift on a numerical evolution algorithm. The Norwegian mathematical physicist Nils Barricelli was writing and testing sequences of computer code "able to reproduce, undergo mutations, and associate symbiotically within the 40,960-bit memory of the new machine" (Dyson, 2012, p. 227). Ironically enough, Barricelli developed his self-replicating digital 'symbioorganisms' to demonstrate that mutual cooperation was more important than the atomized natural selection and random variation components of neo-Darwinian evolution that had been hijacked by neo-Malthusian social Darwinists.
} 
deeply influential Alonso-Muth (Alonso, 1964; Muth, 1969) formulation of spatial equilibrium had the effect of concealing the ruthless struggles of urban class competition behind the elegant calculus of market-clearing locational bid-rent curves. The explicit ethno-racial hierarchies that structured the spatial evolution of the American metropolis -- such as Homer Hoyt's (1933, pp. 314-316) famous ranking of the effect of different racial groups on neighborhood rents in Chicago, from 'English, Scotch and Scandinavians' at the top to 'Negroes and Mexicans' at the bottom -- emerged from interwar America's putrid stew of market democracy and populist Spencerian eugenic racist thought. But all could safely be hidden in the multivariate masquerade of hedonic pricing models and the economic discourse of "property values" as a floating signifier for the dangers of difference. ${ }^{8}$ And the entire theoretical apparatus was hard-wired as the default setting in the mainframes of urban public policy through the deceptively obscure accounting jargon of "highest and best use," distracting attention from the political contradictions of property rights in capitalist urban planning (Krueckeberg, 1995).

This is the historical context that shaped the discourse and analysis of gentrification in urban theory: social Darwinist competition disguised in the naturalized narratives of Chicago-School urban ecology and quantified neoclassical equilibrium. Initial responses to the empirical realities of a process that defied the expectations of mainstream urban theory were dominated by the analysis of individual consumer preference: if gentrification defied the predictions of Alonso bid-rent curves, then obviously the explanation was a shift in the "indifference curves" of

\footnotetext{
${ }^{8}$ In a later chapter, Hoyt (1933, pp. 355-356) describes the inner-city "blight" that shaped U.S. urban renewal policy and that Neil Smith (1979) would later theorize as the rent gap: "a low level of rents and a high percentage of loss in collecting that small amount, a heavy rate of physical deterioration of property caused by waste, neglect, and acts of vandalism, reduce land values in these sections occupied by 'hobos,' seasonal workers, and criminals of Native American stock and by the lowest classes of Mexicans, negroes, and South Italians to a very low point. There is now a valley in the land-value curve between the Loop and the other residential areas..."
} 
wealthy and middle-class households re-evaluating the tradeoffs of time, space, and accessibility (Stegman, 1969; Wheaton, 1977; Schill and Nathan, 1983). ${ }^{9}$ These tautological pivots became the targets for the new revolution in urban theory when Harvey (1973, p. 135) sardonically observed, "All this actually means is that the rich group can always enforce its preferences over a poor group because it has more resources" to exploit all the dimensions of competitive bid-rents. Similarly, Neil Smith's first analysis of the transformation of Philadelphia's Society Hill was aimed squarely at Urbanism, Incorporated: “The Chicago School's latter-day followers have bequeathed to urban geography an empiricist and ecological quagmire in which substantive theory nearly drowned," Smith (1977, p. 7) wrote in the opening pages of his undergraduate honors thesis. This was the first salvo of a lifetime project of politics and research devoted to challenging the friendly, market-tested violence of the "consumer sovereignty" logics that built the foundations of aggressive, state-driven neoliberal urbanism and populist middle-class support for revanchist wars on the poor and homeless. Nevertheless, despite the incisive rigor and political integrity of a generation of critical perspectives on gentrification, an important genealogical insight has been neglected: the entanglement of gentrification with the suppressed memories of social Darwinism. We have forgotten how explicit Glass was in making this connection. Only a few lines after describing how "modest mews and cottages" became "elegant, expensive residences" in an "invasion" spreading from Hampstead and Chelsea to

\footnotetext{
${ }^{9}$ The crystallizing cognitive calculus of late-1960s planning theory was best expressed by a young urban planning scholar who would later go on to serve in the U.S. Department of Housing and Urban Development in the surreal Clinton years of a partially revivified urban policy seen through the parallax view of neoliberal economic deregulation and a seemingly relentless electoral conservative suburbanization of American politics. Michael Stegman (1969) responded to the runaway popularity of transportation models of urban structure inspired by the Alonso-Muth approach by emphasizing the importance of housing and neighborhood aspects of consumer choice: "It is conceivable that while location rents are high near the core because of the concentration of nonresidential activities and the relatively large number of particular consumers who find it either necessary or desirable to live near their places of work, these rents would be even steeper if the available housing were of higher quality and the environment more amenable. [emphasis added] What might accompany such a positive change in housing conditions and environment is a complete reversal of income groups -- the wealthy would occupy the accessible and desirable inner rings, forcing the poor to live on the fringes."
} 
Islington, Paddington, North Kensington, and even the 'shady' parts of Notting Hill, Glass reminded readers of the "neomalthusian" Depression-era assumptions of the Greater London Plan of 1944. The Plan had been amended in 1947 to implement what we would now recognize as neoliberalism: "development rights have been de-nationalized; development values have been 'liberated." (Glass, 1964, p. xx). Along with the weakening of rent controls, these measures quickly accelerated the polarization of the metropolis:

"In such circumstances, any district in or near London, however dingy or unfashionable before, is likely to become expensive; and London may quite soon be a city which illustrates the principle of the survival of the fittest -- the financially fittest, who can still afford to work and live there. (Not long ago, the then Housing Minister advised those who cannot pay the price to move out.)" (Glass, 1964, p. xx).

\section{Decolonizing the New Urban Colonialism?}

The second part of our story involves a paradox of politics, theory, and discourse in the halfcentury since Ruth Glass wrote these words. Can anyone deny that London is a city that illustrates the survival of the financially fittest? From all over the world, the financially fittest capitalists are bidding the top end of the residential market above the \$100 million mark in London and New York (New York Times, 2015), as the "uber-rich" buy homes as "safe-deposit boxes" for cash (Rees, 2015). We're now at half that level here in Vancouver, where a onetime CEO of the San Francisco social media game-maker Zynga recently sold a 25,000 square-foot 
home for $\$ 51.8$ million; the buyer heads a conglomerate with interests in property development, pharmaceuticals, hotel management, and textiles. The buyer grew up in poverty and didn't finish high school, and he failed at his first business venture -- a duck farm (Lee-Young, 2015, p. A6). But Chen Mailin persevered and succeeded; he's worked his way to the top, just like Rockefeller in a previous century, and he's a hot trending topic in Hong Kong, Singapore, and Taiwan. But representing a city -- even a big city like Nanjing -- in the PRC's People's Political Consultative Committee isn't as secure as it once was. Things could change. ${ }^{10}$

All around the world, the "financially fittest" who have survived and thrived in the creative destruction of capitalism's ecosystem (especially in those growth frontiers of savage competition that "pair capitalism with authoritarianism," Dorfmann, 2015) are bidding up real estate prices in a planet-wide search for what the Vancouver urban planner Andy Yan calls "hedge cities" -- safe places to store capital in real estate as insurance for an uncertain future. ${ }^{11}$ These circuits -- what Tom Slater (2015) has carefully theorized as "planetary rent gaps" -- are now the subject once again of evolutionary social physics models and frontier metaphors that would be all too familiar

\footnotetext{
${ }^{10}$ Ian Young, a seasoned and transnational journalist who writes a column titled "The Hongcouver" for the South China Morning Post, cites estimates that between 2005 to 2012, about 45,000 millionaire migrants arrived in Vancouver under two immigrant investor programs -- compared with fewer than 30,000 for the entire United States. "So, Vancouver has recently received more wealth-determined migration than any other city in the world, by a long stretch. This, in a city with some of the lowest incomes in Canada." (Young, 2015). See also Ley (2010, pp. 5664).

${ }^{11}$ Yan's real-estate analyses have been covered extensively in the local press for several years, and were then featured in a short piece in the New Yorker (Surowiecki, 2014) -- a degree of attention from above on the urban hierarchy that was in turn noted by a local writer frustrated with life in the ghost-town blocks of investor-owned properties in one of Vancouver's epicenters of transnational super-gentrification (Saddy, 2015). Yan's work was subsequently featured in the Harvard International Review (Dorfmann, 2015). An alternative formulation of the "hedge city" idea was offered by Lawrence D. Fink, head of the world's largest hedge fund (BlackRock), at a conference in Singapore: "Historically, gold was a great instrument for storing wealth," but now, "the two greatest stores of wealth internationally today [are] contemporary art ... and, two, the other store of wealth today is apartments in Manhattan, apartments in Vancouver, in London.” (cited in Yaffe, 2015, p. D2). Still another formulation was offered by Albert Lo, a realtor and head of the Canadian Race Relations Foundation, describing immigrants who "park large amounts of money" in Canadian real estate and then "go back to work in China" or elsewhere (quoted in Todd, 2015, p. A5).
} 
to Robert Park and Frederick Jackson Turner. The prolific science writer Philip Ball -- an editor at Nature and contributor to the Financial Times who has chronicled the new field of "econophysics" (Ball, 2006) -- writes a story in the Guardian making the case that "Gentrification is a Natural Evolution," based on a paper published in the journal Physics and Society. Those authors, Ball (2014) tells us, "are studying city evolution much as biologists study natural evolution -- almost as if the city itself were a natural organism" -- what Jane Jacobs called "the spontaneous self-organization of urban environments." Mark Buchanan, another Nature editor, chronicles the "quantum revolution" of "social physics" in the example of Thomas Schelling's "atomic physics" interpretation of the "social cascades" that took place at the "fringe between civilization and lawlessness": Times Square (Buchanan, 2007, p. x, 102, 22). The pioneers in this lawless urban fringe included Viacom, Bertelsmann, Morgan Stanley, and the Walt Disney Company. Similarly, Ed Glaeser -- a twenty-first century Richard Ely who has become the celebrity intellectual $d u$ jour among the world's leading capitalists, praises cities -but only those dynamic, entrepreneurial free-market cities that "speed innovation by connecting their smart inhabitants to each other," serve as "gateways between cultures and markets" or as "gateway[s] to ideas" (Glaeser, 2011, p. 7). For Glaeser, the city, collective humanity's greatest invention, "makes us richer, smarter, greener, healthier, and happier," and it makes us an "urban species." But we are also a gentrifying species, and a gregarious, networked species. Tom Slater (2014) strikes up an email correspondence with Ball, and publishes an eloquent response: "There is Nothing Natural About Gentrification." The apparent sophistication of complexity theory used to predict where gentrification will happen next should not confuse us, Slater warns; this is "a dangerous diversion towards social Darwinism," ignoring "structural forces of power, politics, policy, and privilege." Not long after Spike Lee is heard on an audio recording at a Pratt 
Institute lecture honoring African American History Month calling the gentrification of Fort Greene "Motherfuckin' Christopher Columbus syndrome," a New York Times editorial manager sends a note to the newsroom asking reporters to please stop describing neighborhoods in every city from Beijing to Cape Town in terms of how much they resemble hipster Brooklyn (Nguyen, 2014). But it was already too late. The \#Christophercolumbussyndrome hashtag entered the twittersphere and was carefully dissected in an article in the daily online Spanish finance and politics site El Confidential -- 'Es el puto síndrome do Christóbal Colón' (García-Ajofrin, 2014) -- amidst powerful structural imperatives. In the early 1970s when Harvey and Smith were first refining Lefebvre's theory of the capital-switching dynamics of the production of urban space, global capital had to find profitable investment opportunities for about $\$ 6$ billion of annual surplus value; now that figure is more than $\$ 2$ trillion every year (Harvey, 2014, p. 228). Most of that is going into cities. And almost a century after Robert Park declared the city a product of human nature and Patrick Geddes foresaw a "neotechnic order," the technologies of unprecedented planetary connectivity are accelerating the evolution of accumulation away from the old industrial capital of the Global North towards the new informational empires as well as cosmopolitan capital of all kinds from the Global South. John D. Rockefeller and Andrew Carnegie are replaced by Bill Gates, Tim Cooke, Mark Zuckerberg, and Rupert Murdoch, but also by Chen Mailin, Jack Ma, Carlos Slim, and Mukesh Ambani. Planetary connectivity is also allowing the kinds of communication that Park and Dewey first theorized at the scale of the city to now reach the scale of Lefebvre's planetary urbanization. Woven from contextual blends of indigenous local processes and fast-moving policy innovations, gentrification has gone global. 
Let me be clear on this point. When I argue that gentrification has gone global, I am not suggesting that the phenomenon Ruth Glass identified in London in the 1960s -- and that many researchers have investigated and discussed in subsequent years -- began in the Global North and has now been simply copied or applied in cities of the Global South. Gentrification (as a process, not a word) has a deeper history and a wider geographical lineage than is usually recognized (Lees et al., 2015a, 2015b). Rather, I contend that the varied forms of the competitive class reshaping of urban space that have always defined urban modernity are sufficiently pervasive and transnationally connected through flows of ideas, money, and aspirations to be reasonably considered part of something "global" in reach and influence.

As gentrification has gone global, so have Frederick Jackson Turner's frontier metaphors. They're on the ground and in the cloud, in the streets and in the tweets, as the frontier as "a moving section," a "form of society" (Turner in 1914, quoted in Bowman, 1932, p. 499) replaces Charles Galton Darwin's (1956) "genetic surgeon" with an emergent transnational social field of escalating multicultural competitions in education, employment, and housing. One future of gentrification is clear from Ley's (2010, p. 82) analysis of Vancouver's position at the nexus of "a dispersed social and spatial field" of 'trans-pacific life-lines' for competitive, entrepreneurial middle-class and elite families that incorporate "the capital-generating station of East Asia with the family-nurturing station of Canada into a single life-world." Such transnational fields are now apparent across a growing number of cities, and fortunes are being made by those entrepreneurial pioneers of the noösphere who move quickest to adapt and exploit the new "science of collective behavior" (Park, 1921) on the frontiers of transnational spatial fixes of informational capital. The processes Harvey (1989, Chapter 8) diagnosed a generation ago as the 
"urbanization of consciousness" are now operating through a global noösphere in an interconnected, evolutionary, and variegated planetary urbanization.

As situated, embodied, and urbanizing individuals, each of us can see, understand, or experience particular empirical facets of this latest urban revolution -- and now billions of us are also able to talk, learn, and fight about it in real time, in the evolutionary algorithmic ecosystems of social media. No wonder John Sexton, with that doctorate in religion from the Jesuits, thinks in Teilhardian terms. He's in the noöspheric administration of one of the most exclusive private universities in one of the world's most widely-recognized epicenters of gentrification, where admission requires a "superstage of consciousness" of grades, test scores, and extracurricular achievements -- along with ever-escalating tuition payments and a Hunger Games survival of the financially fittest competition in the City's housing market. NYU's "real estate footprint" in Greenwich Village and Brooklyn has grown by more than two million square feet in the past decade, while Sexton responds to critics of the "globalization of the university" by contextualizing the competition: "I live in a city where the people with all the choices, all the money, all the information, kill to get their kids into $\$ 35,000$ kindergartens" (quoted in Carapezza and Noe-Payne, 2014). He's right, and so is Spike Lee when he describes the cutthroat competition of White parents to get their kids into private schools, ${ }^{12}$ and when he describes the next generation of pioneers in Harlem: "When you see White mothers pushing their babies in strollers, three o'clock in the morning on 125th Street, that must tell you something" (quoted in Coscarelli, 2014). Meanwhile, the acceptance rate for NYU Abu Dhabi's second entering class stood at 2.6 percent -- a group of slackers compared to the previous year's

12 “...There's a business now where people -- you pay -- people don't even have kids yet and they're taking this course on how to get your kid into private school. I'm not lying!" (quoted in Coscarelli, 2014). 
1.2 percent -- and NYU Shanghai's recruitment criteria have been fully integrated with China's informational intravenous drip ${ }^{13}$ gaokao National College Entrance Examination. Even so, Sexton's Teihardian new frontier of "idea capitals" cannot always evade the Limits to Capital (Harvey, 1982): NYU's Tisch Asia biz-school gamble in Singapore failed after a cascade of embarrassing financial and management crises.

This is the new urban frontier, half a century after Ruth Glass established the link between gentrification and the survival of the financially fittest in the global city. Unfortunately, critical perspectives on planetary gentrification have been distorted by a new paradox of theory, politics, and practice. A half-century of theory and discourse built to analyze the causes and consequences of the systemic socio-spatial inequalities of gentrification -- what Atkinson and Bridge (2005) call the "new urban colonialism" -- is now itself under scrutiny as a colonial imposition. Considering the catastrophic history of evolutionary hierarchies and developmental teleologies that continue to define the colonial present, this new challenge can be seen as a cosmopolitan, emancipatory evolution beyond the narrow view from Anglo-America -- what Jim Blaut (1993) famously called the "colonizer's model of the world" (see also McCann et al., 2013; Harris, 2008; Ren, 2015; Lees et al., 2015a, 2015b; Baptista, 2013).

\footnotetext{
${ }^{13}$ A widely-circulated image from news reports in May, 2012 showed students in a high school in Hubei Province hooked up to intravenous drips of amino acids to help them study for the upcoming gaokao. The brutally competitive high-stakes exam "has become the target of criticism and national reform because it is considered the root cause of all education ills in China: from the lack of innovation and creative citizens to deteriorating health among children, from widespread cheating and fraud to student suicides, and from massive inequality in education opportunities to unbearable academic pressure on students." (Zhao, 2009, p. 49).
} 


\section{The Cosmopolitan Decolonization of Gentrification}

Three recent landmarks in the gentrification literature offer lucid expressions of this new critical view. First, Thomas Maloutas (2011) offers an eloquent and strident challenge to the contemporary geographical and theoretical expansion of gentrification research. Gentrification, Maloutas argues, is "highly dependent on contextual causality," and no amount of conceptual reconstruction can "remove its original contextual attachment to the Anglo-American metropolis" (p. 34). For Maloutas, the "spatiotemporal stretching" of definitions of gentrification is not only a "regression in conceptual clarity and hence theoretical rigor," (p. 36) but has itself become a part of the established Anglo-American hegemony of academic knowledge production; "there are authors from far less commensurable contexts that are increasingly compelled to label changes within urban centres as gentrification," (p. 37) even when the conclusion is analytically inappropriate. "It is somewhat ironic that radical thinkers like Saskia Sassen and Neil Smith contribute indirectly to this effect," Maloutas (2011, p. 42) argues, "by reinforcing the image of neoliberal omnipotence through their critique of a regulation model that bursts out of its contextual confines due to the Anglo-American domination in the discipline." Maloutas is deeply concerned with the simultaneous, mutually reinforcing disempowerment of researchers and theoretical concepts from the Global South, and the "contextual blindness" of researchers in the Anglo-American core -- and thus he concurs with Butler's (2007, p. 163) response to Atkinson and Bridge's (2005) diagnosis of a 'new urban colonialism': "the issue of 'neocolonialism' is as much with the use and definition of the term as with its consequences." 
Second, Loretta Lees (2012, p. 156) has recently challenged us to move "away from an 'imitative urbanism' (from the idea that gentrification in the Global North has travelled to and been copied in the Global South) towards a 'cosmopolitan urbanism' (where gentrification in the Global South has a more expanded imagination)." Lees (2012, p. 158) gives us a clear warning: "We should not read gentrification in the Global South as simply the recreation of the periphery (the urban South) in the image of the supposed centre (London or New York)." Lees calls for postcolonial comparative urbanist analysis of the "hybridity of neoliberalism," and "new, indigenous, and cosmopolitan theorizations" of gentrification in the Global South as well as the Global North.

Third, in a valuable, deeply contextualized analysis of the curious absence of gentrification discourse amidst the dramatic urban transformations of Hong Kong, David Ley and Sin Yih Teo (2013) explore the intricate ambiguities between epistemology and ontology. Drawing on Aihwa Ong's (1999) concept of “alternative Asian modernities," Ley and Teo document a chorus of voices from the Asia-Pacific that challenge the dominant Anglo-American narratives of neoliberalization -- emphasizing instead the distinctive built forms and political processes that culminate in the synthesis of market and state power in the constitution of a "joint urban project" (p. 14). Urban renewal is fused with national developmental imperatives. Crucially, this alternative Asian modernity holds out the promise, Ley and Teo (2013, p. 1) write, "most surprising from a Western perspective," of "a potentially progressive dimension for some impacted residents" through systems of negotiated compensation and broad improvements in housing conditions. "[T]he cultural hegemony of property in Hong Kong and other parts of East Asia makes redevelopment of some low-income districts a more ambivalent process," Ley and 
Teo conclude, "for locked within the displacement of redevelopment is the hope of a negotiated settlement with the state leading to improved housing."

This emergent movement for a 'cosmopolitan decolonization' of gentrification research expresses the best of intentions -- and, in crucial ways, the very best achievements of cuttingedge idealist innovation in critical theories that have become deeply reflexive, sensitive to context, and committed to emancipatory possibilities in the "processes of ascendence, emergence, and contestation that defy the grid of postcolonial world systems" (Roy, 2011, p. 308; cf. Ong, 2011). It challenges those of us who write from and about gentrification in the Global North to look beyond the narrow confiness of Northern cities, while also realizing, as Maloutas (2011, p. 43) reminds us, that only a tiny fraction of the world's urbanites live in "the core cities that set the ways of seeing and understanding socio-spatial change that often become the deforming lenses through which we examine what happens in the rest." Yet our deferential reverence to the analytical sophistication of cosmopolitan contingency intensifies a striking paradox: today's postcolonial theory has achieved what Global North growth-machine operatives have been trying to do ever since the Real Estate Board of New York took out expensive ads on the editorial page of the New York Times, asking "Is Gentrification a Dirty Word?" (Smith, 1996). "Oh, we don't have any gentrification here," an "eminent researcher of the rise of the Taiwanese middle class" tells Eric Clark (2015, p. 453) on a research visit to Taipei, in a confident assertion of the kind repeated at every opportunity, in every language, by developers, state officials, and professionals in every city that is being remade, rebuilt, regenerated, renewed, or revitalized. Alternative urban modernities that defy the contextual specificities of Anglo-American gentrification while showcasing how "diverse actors and 
institutions invent and aspire to new ways of being global" (Ong, 2011, p. 23) nevertheless involve the displacement of nearly a tenth of Shanghai's population in a single decade (Iossifova, 2009), 720 thousand for the Seoul Olympics (COHRE, 2007), 3.45 million across the AsiaPacific between 2003 and 2006 (COHRE, 2006), and at least 1.5 million for the Beijing Olympics (Shin, 2012). Along with the uncounted millions displaced by the kinder, gentler violence of market forces, these are the costs for which the cosmopolitan turn provides no vocabulary, no language of questions or resistance. There is a world of difference between a politics that challenges gentrification as the new urban colonialism (Atkinson and Bridge, 2005) and one that attacks the terminology, theory and politics of the critical analysis of gentrification as an apparatus of colonial domination. This would not be the first time that critical sensibilities of an inclusive, progressive poststructuralism were hijacked to serve the purposes of deeply retrograde authoritarian alliances (compare Smith, 2009 with Cartier, 2015 for perspectives on 'Western' and 'Eastern' variants of authoritarian state coercion). At precisely the moment when gentrification is becoming truly transnational and powerfully planetary, we are asked to liquidate the intellectual and political investments of generations of critical inquiry in favor of evolving theories of "globalized contingency" that have now even attacked postcolonial theory itself as "hegemonic" (Ong, 2011, p. 3, p. 8).

There can be no doubt that we need an "expanded geographical imagination" (Lees, 2012) to understand the varied and cosmopolitan causes, textures, and consequences of the class transformation of urban space in different circumstances. Yet for three decades now, gentrification researchers have undertaken comparative inquiry with a deep sensitivity to the "contingency and complexity, set within the structural dimensions of advanced capitalism" that 
Beauregard (1986, p. 35) called for; Lees et al. (2015b, p. 6) review the "significant debate in the 1990s about the contextual nature of gentrification," and cite a wide range of contextual and/or comparative gentrification studies beyond the "usual suspects." Today, however, as the "advanced capitalism" once synonymous with the Global North shifts to the urban growth frontiers of the Global South, the 'cosmopolitan decolonization' of gentrification theory abandons the analytical and political potential of all of this work. Lees et al. (2015b, p. 7) highlight the stakes when introducing their new edited collection of genuinely cosmopolitan and pluralist analyses of 'global gentrifications':

"Without a gentrification theory that serves as an 'umbrella' ... the debate we are holding now in this book would probably not exist, neither would most of the gentrification debates held hitherto by scholars in different contexts, and nor would urban activists around the world be able to identify the different types of redevelopment-led displacement that are in many ways part of the same repertoire of class restructuring in global capitalism."

Moreover, the central features of an allegedly distinctive Asian urban paradigm -- aggressive and comprehensive state planning, contested yet significant systems of relocation and compensation, and what Maloutas calls the "cross-class national pride" of urban modernization -- only present a contradiction of gentrification theory if we retreat to the most narrow, obsolete, and rigid definitions tied to "classical" Glass-style spontaneous invasion-and-succession of particular inner-city neighborhoods, thus ignoring the vast, interdisciplinary, and contextual literatures on urban renewal, state-driven gentrification, and intensified capitalizations of home and urban life involved in far-flung transnational networks of real-estate securitization, development, and 
speculation (Lees et al., 2010; Shao, 2013; Slater, 2015; Smith, 2002, 2010; Harris, 2008).

Indeed, it is far more meaningful to suggest that the contextual, indigenous fusion of the "process of value extraction from the built environment" (Lees et al., 2015a, p. 441) with consolidated Asian nation-state power and popular consent in the assemblage of development models and tactics from "parts of elsewhere" (Allen and Cochrane, 2007, p. 1171) in the "nodes of an emergent global order marked by the ascendancy of Asian powerhouses, from the Gulf States to India and China" (McCann, Roy, and Ward, 2013, p. 585) -- all of this constitutes the refined achievement of a gentrification project that is far more effective than anything ever accomplished in the Anglo-American world. It is testament to the success of gentrification in developmental states that the word "gentrification" is so rarely used: a pre-emptive eviction of the term helps delay and suppress the politics of resistance (Slater, 2009), and in any event, resistance is always a marginalized minority against the discursive and material popularity of the "spatialised production of new middle-class urban identities" (this is Harris's [2008, p. 2415] memorable phrase inspired by Fernandes' [2006] analysis of India's new middle class). Ley and Teo (2013), however, document a recent "ontological awakening" amidst worsening inequality in Hong Kong, while there are other indications of instability in the twenty-first century's dialectical response to the Chicago School -- the "Chinese exceptionalism" urban paradigm (Ren, 2015; cf. Cartier, 2015). No matter what it is called -- urban renewal, regeneration, development, modernization, the cultural hegemony of property, the spatialised production of new middle-class urban identities, the "often invisible, unquantifiable" "human wreckage" of a domicide translated as chaiqian (demolition + relocation) (Shao, 2013, p. 2), or the 2010 Shanghai World Exposition's unbridled optimism of "Better City, Better Life!" -- this is the 
nationalization of gentrification within the transnational interconnections of planetary urbanization. This is the essence of gentrification, not its Other.

\section{Gentrification and the Noösphere}

My third claim is the most provocative, because it puts me in the position of attacking the emancipatory narratives of multicultural meritocracies of competition in technology, creativity, and education. Contemporary gentrification is a recombinant urbanism of old and new, defined by competitive processes accelerated through the algorithmic transformation of market relations in housing, labor, and education. Silicon Valley's noösphere involves an unprecedented and unapologetic planetary colonization by the West: Facebook's plans for a fleet of a thousand high-altitude drones flying over 4G LTE terra incognitae to connect the unnetworked savages is code-named Aquila, for the classical-mythology eagle carrying Jupiter's thunderbolts to the sky. Algorithmic imperialism is reproducing dangerous new frontiers of Turner's evolutionary logics in dynamic transnational urban networks of class competition. In an essay written not long before his "Evolution of Gentrification" chapter, Neil Smith (2009, p. 54) challenged the idealism of poststructuralism for "engender[ing] the implicit assumption that to change the world it is necessary first and foremost to change the discourse," as against the structured material inequalities of class in the capitalist mode of production. Yet this distinction has quickly blurred in the years since the global financial crisis, as the most dynamic frontiers of capital accumulation are now pursuing the commodification and monetization of discourse itself on a planetary scale. Apple first surpassed Exxon in August of 2011 to become the world's most valuable company in terms of market capitalization, and is now valued at $\$ 719$ billion; 
Facebook’s market cap, at \$232 billion, recently surpassed JP Morgan; Google posted revenues of $\$ 66$ billion last year, 89 percent from advertising. If we take a broad view of the old and new names in cognitive-cultural capitalism (Scott, 2007, 2011a, 2011b) ranked by market capitalization, we see Apple, Google, Microsoft, China Mobile, Facebook, Verizon, Oracle, Disney, Amazon, AT\&T, IBM, Comcast, Intel, Cisco, Taiwan Semiconductor, and Qualcomm; this is a combined market capitalization of $\$ 3.66$ trillion devoted to an informational mode of production in which the human attention span is being assembled into a transnational resource to be dynamically measured, managed, and mined. Poststructuralism is the new retail frontier ${ }^{14}$ for Wall Street finance, Silicon Valley venture capital and technological innovation, and a remarkably cosmopolitan global alliance of emergent middle classes, political elites, and energetic, idealistic students in a variegated planetary urbanization of cognitive capitalism.

In this context, a wider array of individuals, firms, public and private institutions in cities -- even the most "ordinary" cities (Robinson, 2006) -- are forced to compete and adapt across an increasingly dynamic, insecure, and expanding networked noösphere of accelerating measurement and marketization in housing, employment, and education. Urban assets -- their real-estate markets, their educational institutions, their 'human capital' -- are all being mobilized more aggressively, more creatively, and more rapidly in the pursuit of endless compound growth and capital accumulation (Smith, 2000, 2002; Harvey, 2014). Cognitive capital accumulation, however, is much more agile compared to the old growth-machine urbanism of the industrial age

\footnotetext{
${ }^{14}$ The wholesale frontier includes the less visible but more lucrative circulatory infrastructure of corporate capitalism. Amazon Supply is a B2B (business-to-business) e-commerce site targeting wholesale distribution -initially, among the 35,000 separate enterprises in the United States. Amazon booked \$74 billion in revenues in 2013, but aspires to the $\$ 8$ trillion distribution market in the U.S. and then beyond. As Prentis Wilson, head of Amazon Supply, explains: "Our goal is to supply everything needed to rebuild civilization" (quoted in O'Connor, 2014, p. 89).
} 
-- and it offers alluring images of inclusion, opportunity, and diversity in Richard Florida's globally-circulating " $3 \mathrm{~T}$ " formula for urban success: technology, talent, and tolerance. "In the Creative Age," Florida (2003, p. 17) emphasizes, "the mind itself becomes the mode of production, so to speak," and the shift from an economy based on material inputs to one driven by intellectual resources elevates the importance of meritocracies -- measurable and quickly adaptive meritocracies -- in workplace divisions of labor and in the colleges and universities that function as "talent machines" in the "new global competition for talent" (Florida, 2006). Together, all of the interdependent processes by which the "basic cognitive-cultural system of production" is "transforming the economic foundations of many large metropolitan areas all over the world" (Scott, 2011b, p. 289) are dissolving the relevance of the sharp categorical distinctions and polarizing binaries of the gentrification debates: demand-side and supply-side causal explanations (Smith, 1987; Ley, 1987; Hamnett, 1991), the role of ethnoracial and cultural lifeworlds as opposed to the calculative rationalities of profit and loss (Rose, 1984; Knopp, 1997; Taylor, 2003), and the fine-grained morphological differences among residential, retail, and industrial redevelopment, or 'classical' versus 'new-build' reinvestment (Lambert and Boddy, 2002; Davidson and Lees, 2010). Each of these lineages of theoretical and political debate is important so long as gentrification is understood as a spatially-bounded process that happens in specific, localized city neighborhoods with distinctive histories and built-environment characteristics. These issues matter less when gentrification is understood as a dimension of planetary urbanization, as Merrifield (2013, p. 916) frames it: "The urban brings everything together, and transforms everything in that coming together: capital and goods, people and information, activity and conflict, confrontation and cooperation." If we take Lefebvre 
(2003[1970], pp. 118-119) seriously, the urban is pure process: "a place of encounter, assembly, simultaneity," but a non-place, a

"concrete abstraction, associated with practice. ... the urban accumulates all content. But it is more than accumulation. Its content (things, objects, people, situations) are mutually exclusive because they are diverse, but inclusive because they are brought together and imply their mutual presence. The urban is both form and receptacle, void and plentitude, superobject and nonobject, superconsciousness and the totality of consciousness."

What does this mean for the evolution of gentrification? When understood as a dimension of planetary urbanization, gentrification is no longer confined to a false choice between the chaos and complexity of localized geographical contingency as opposed to the order and simplicity of land, property, and class (compare Beauregard, 1986, with Clark, 2005). Gentrification is, as ever, the upward class transformation of urban space. Just as planetary urbanization redefines the ontology of "urban," however, "class" can and does take on altered meanings in cognitive capitalism. The axes of class analysis are realigned both for Marxian conceptualizations in relation to the means of production of surplus value, and for Weberian orders of class, status, and power -- as well as the interrelations of "class and its others" (Gibson-Graham et al., 2000) of race, ethnicity, gender and sexual identity, age, and other axes of difference. Class inequalities are deeper than ever, but these multiple dimensions are subject to reconfiguration amidst the rising informational content and increasingly algorithmic nature of production, consumption, governance, education, and social reproduction in cognitive capitalism. The accelerating scope 
and pace of these reconfigurations -- experienced and threatened shifts in market demands, for instance, and the Silicon Valley 'disruption' of various occupations and industries -- are returning the concept of "class" to more of the original meanings intended by Galton and Pearson: any system of social ranking, categorization, or classification used to determine hierarchical difference.

It should now be clear that understanding the upward class transformation of urban space requires that we expand our imagination of gentrification (Lees, 2012; Lees et al., 2015a, 2015b) -- not to provincialize it to particular neighborhoods, cities, or regions (Maloutas, 2011). The upward class transformation of urban space is manifest in any empirical situation where individual or group differences result in a more powerful group coming to dominate any urban 'place of encounter. ${ }^{15}$ In market systems for housing, labor, and education, hierarchies of power involve economic competition for urban locations, but of course all societies are also constituted by other inequalities of identity, difference, and power. These inequalities come together in varied ways in different cities, but the recognition of postcolonial pluralities, contingent causes and consequences, and de-centered "sites of epistemological production" (Baptista, 2013, p. 590) should not blind us to the generic power (Clark, 2015, p. 454) of two universals: 1) competition, and 2) classification systems that distinguish individuals and/or groups. While in capitalism money provides the ultimate classification system, cognitive-cultural capitalism is defined by

\footnotetext{
${ }^{15}$ Contemporary literatures on gentrification are enriched by theoretical and empirical innovations tracking the evolution of difference, class, and the multiply-scaled circulation of meanings and discourses in cognitive-cultural capitalist urbanism. For examples focusing on the local politics and competitive marketing on the 'culinary frontier' of restaurants in Vancouver, see Aiello (2014) and Burnett (2014); on the 'ideological lineage' from eugenics to contemporary psychopathology at the nexus of gentrification, homelessness, and severe mental illness, see Durgan (2013); on the cultural politics of neighborhood representation and the corrosive effects of gentrification on the meanings of local cultural practices, see Alfasi and Ganan (2015) on Jerusalem, Parekh (2015) on New Orleans, Chang (2015) on 'aesthetic regulation' in Singapore, and Scott (2011b) on "aestheticized land-use intensification" in a variety of cities of the cognitive-capitalist "third wave."
} 
increasingly diverse pathways from cultural identity and creativity to the valorization of success through competition. This competition is increasingly mediated through socially-networked information technologies and other changes in the infrastructures of observation, measurement, and classification that govern the development and certification of human capital, the management of the creative powers of cognitive labor, and the advertising-driven monetization of human social relations, attention, and learning.

The gentrification literature has, for entirely understandable reasons, focused heavily on realestate and land-market dynamics: the rhythms of real-estate capital investment and disinvestment are crucial moments and measures of class transformation. But today's cognitive capital interweaves real estate capital flows with media and educational discourses and communications circuits in ever more powerful and creative ways. We need to take LinkedIn CEO Jeffrey Weiner very seriously, then, when he outlines the goals of the company's recent acquisition of the online learning enterprise lynda.com, as part of an effort to expand the "addressable market by $\$ 30$ billion": "We want to digitally map the global economy, identifying the connections between people, companies, jobs, skills, higher educational organizations and professional knowledge and allow all forms of capital, intellectual capital, financial capital, and human capital to flow to where [they] can best be leveraged." (quoted in MarketWatch, 2015). We also need to take seriously the rapidly changing relations among informational innovation, the accumulation and circulation of capital, and the legal rules of state and corporate surveillance. We know that there's a bizarre, retroviral sort of transnational regeneration underway when Mark Zuckerberg pays $\$ 100$ million for a 750 -acre parcel on the North Shore of Kauai that includes a former sugarcane plantation (Stone, 2015), while requiring the carpenters 
and laborers renovating his house in San Francisco to sign detailed non-disclosure agreements (Richtel, 2015), while ostentatiously staging a copy of Xi Jinping: The Governance of China on his desk at Facebook headquarters so that Lu Wei can pause and smile as a photographer captures the moment: "One photo taken of the Facebook visit and posted on a site associated with China's State Council Information Office shows Mr. Lu smiling as he looks down at the book." (Mozur, 2014). Lu Wei is described in the West as "China's Internet Czar," but that's a bit out of date in an age when Zuckerberg can say with a straight face that he bought Lu Wei's book so that he and his coworkers "understood socialism with Chinese characteristics" (Mozur, 2015) by carefully studying the wisdom of the Minister of Cyberspace Administration who has worked so hard and so skillfully to measure, monitor, and manage (i.e., suppress) online discussion of social movements resisting demolition and relocation in China's domicide (Shao, 2013; also see Mozur and Perlez, 2014 ${ }^{16}$ ). We've come a long way from John Sexton's appeal to JFK's anticommunist "new frontier" as he works to build the Global Network University.

In the age of the "stretch-limo optimism" of the Reagan years, Neil Smith mused:

"No one has yet seriously proposed that we view James Rouse -- the developer responsible for such maverick downtown tourist arcades as Baltimore's Inner Harbor, South Street Seaport in New York, or Boston's Faneuil Hall -- as the John Wayne of gentrification, but insofar as such projects serve to anchor the

\footnotetext{
${ }^{16}$ Mazur and Perlez (2015) provide an account of Lu Wei's "well-publicized dinners at fancy Beijing restaurants" with China's 'Big V's, referring to the 'verified account' social media icons with "millions of online followers" who "had already shown how they could turn sensitive subjects -- like forced relocations and environmental problems -into national debates that upset the Communist Party." Robert Moses worked the media when he was taking a "meataxe" to the Bronx, but his tools and informational skills appear quaint and primitive when compared to Snowden's NSA and Lu Wei's Ministry of Cyberspace Administration.
} 
gentrification of many downtowns, the proposal would be quite in keeping with the frontier discourse." (Smith, 1996, p. xv).

Today, no one has yet seriously proposed that we view Lue Wei or Mark Zuckerberg as the agents of Spike Lee's Christopher Columbus syndrome. But the proposal would be quite in keeping with a Silicon Valley frontier discourse in which Obama tells a cybersecurity conference at Stanford, "This cyberworld is sort of the Wild West," not long after the PRC's image of Lu Wei and Zuckerberg scored a photo-op nearly as prominent as the famous February, 2011 White House image of a private dinner in San Francisco where Obama raises a toast to Zuckerberg, Steve Jobs, and the CEOs of Google, Yahoo!, Twitter, Oracle, Netflix, and Cisco Systems. LinkedIn wants to allow all forms of capital -- intellectual, financial, and human -- to flow where they can best be leveraged, but has agreed to censor some of its content in order to gain access to the unprecedented growth frontier of the planet's largest stock of urbanizing human capital (Mozur, 2014).

\section{Turner's Noösphere}

Now we can begin to see the full implications of the Global Network University as a cyborg MOOCification ${ }^{17}$ of Chicago School urbanism, the cosmopolitan patriots as post-Galton-esque, non-hereditary genius descendants of Frederick Jackson Turner, and John Sexton's “tremendous opportunity in the process of global evolution" in the Teilhardian noösphere mutating into a

\footnotetext{
${ }^{17}$ MOOCs are Massive Open Online Courses, an intensely-hyped development at the intersection of information technology, education, and globalization. The potential scale was most clearly demonstrated in 2011, when the former head of Google X and online learning firm Udacity, Sebastian Thrun, offered an online course on artificial intelligence at Stanford. Some 160,000 from more than 190 countries signed up for the MOOC, and approximately 14 percent obtained a Certificate of Completion.
} 
ruthlessly competitive capitalist colonization of Dewey's cognitive Darwinism. "We began to create a new industrial revolution inside people's heads," Richard Florida proclaimed in a community summit -- "Innovation: The Shock of the Possible" -- in the Queen Elizabeth Theatre in Vancouver in the Fall of 2014, in the same month Pope Francis spoke at the Pontifical Academy of Sciences and "appeared to endorse two major scientific concepts that have given religious believers big trouble: the Big Bang and evolution" (Mooney, 2015). Richard Florida's creative-class capitalists embody the new industrial revolutions going on inside their heads, in the survival-of-the-fittest competition of urban entrepreneurialism in the age of planetary urbanization. The cognitive revolutions that inspire Florida are also the focus of neo-classical, neo-liberal economics ${ }^{18}$ at the nexus with neurobiology, behavioral psychology, Big Data, and the thriving 'neuromarketing' literature that gives us articles with titles like "Evolutionary Neuromarketing: Darwinizing the Neuroimaging Paradigm for Consumer Behavior" (Garcia and Saad, 2008). ${ }^{19}$ To really understand the frontiers of accumulation by information, however, Florida's boosterism -- he praises Vancouver as "the most beautiful city on the planet" -- was

\footnotetext{
${ }^{18}$ Recent economics literature highlights dramatic mutations of the consumer sovereignty, demand-side theories that Neil Smith fought against for decades. The "exponential rise" (Hodgson, 2009, p. xxii) of Darwinism in economics has paralleled and reinforced the neoliberalization of space, of urban theory and policy (Peck and Tickell, 2002). Edward Wilson's 'sociobiology' has coalesced with Gary Becker's (1976) suggestion of a "genetic determination of ... human behavior modelled along neoclassical lines," Arthur Robson's (2009) attempt to "show how Darwinian evolution would lead to utility-maximizing behavior consistent with the standard axioms of rationality," and Kenneth Binmore's (2005) use of game theory to build an "evolutionary theory of morality and natural justice, while retaining utility-maximizing agents" (all quotes from Hodgson, 2009, p. xxiii, xxv, xxv). The "explosion of research in economics inspired by evolutionary thinking" (Dopfer, 2005, p. 3) has been so intoxicating for the possibility of hacking the source code of homo sapiens oeconomicus (HSO) as "the basic unit of an evolutionary" paradigm that economists have become uncharacteristically reflexive on the secrets of their success: "What are the factors that may conceivably account for the present dynamism of evolutionary economics? We get a first hint when we consider that, in their field of study, orthodox economists encounter decreasing marginal returns with respect to new theoretical findings per additional unit of research effort or research time. Linking this with the conjecture that creative minds are attracted by new opportunities for developing their theory enables us to obtain a hypothesis that accounts for the phenomenon that outstanding neoclassical economists are increasingly turning to research areas that can be linked to evolutionary ideas." (Dopfer, 2005, p. 3).

${ }^{19}$ The "neurological" turn is only the most extreme case of a wider quest to develop a science to understand the innovative genius of homo urbanus and homo creativitus (Florida, 2014, p. 8). Florida's recent creative-class work fuses psychology, geography, and urban economics in a new human-ecology "psychogeography" to understand the role of "geographic clusters of openness to experience" on the pace of "regional economic and cultural development" (Florida and Mellander, 2014, p. 261).
} 
just a warmup act for the main event: Ray Kurzweil. Kurzweil is "one of the world's leading inventors, thinkers, and futurists," and Forbes has called him "the ultimate thinking machine" (SFU Public Square, 2014). Kurzweil is a cartographer of the new evolutionary frontier of exponential advances in information processing, biotechnology, communications, and neuroscience in the "law of accelerating returns" -- "the inherent acceleration of the rate of evolution, with technological evolution as a continuation of biological evolution" (Kurzweil, 2005, p. 7). Technological advances are speeding up our evolution so fast that we're on the verge of extending life expectancy by more than a year each year -- so if you can just hold on a bit longer, he reassures us, we'll get to a technologically enabled immortality -- the Singularity. "Ultimately, everything is going to be information," Kurzweil emphasizes, including our consciousness. Today's genetic engineering successes on a few of the 23,000 software programs inside us will be "a million times more powerful twenty years from now." The latest generation of Parkinson's treatments have implants in the brain with software updates delivered from outside the patient's body, and soon we will "basically put our brain on the cloud." "We will be a hybrid of biological and nonbiological thinking," Kurweil explains. When he's asked a question about education, he answers with an insistent optimism: "Nanobots in the neocortex will communicate with the cloud," and "nanobots communicating with neurons" will serve as "brain extenders" that will become available to more and more people -- not just the rich. "We are already integrated with our brain extenders," he observes, and at one point Kurzweil holds out his cell phone and tells the audience, "It's a gateway from my brain to the cloud." Kurzweil is only the most affable and mainstream ambassador of a diverse "transhumanism" movement that ranges all the way from corporate singulatarians (such as Peter Thiel, co-founder and former CEO of PayPal, Google's Larry Page and Sergey Brin, and Sun Microsystems founder Bill Joy) 
to "anarcho-capitalist" libertarians and DIY biohackers in communes with names like Cyberpunk Apocalypse (Flatley, 2015). The movement also includes techno-eugenics advocates like Zoltan Istvan, whose manifesto "It’s Time to Consider Restricting Human Breeding" combines admiration for China's one-child policy with praise for "a new transhuman-inspired birth control device" developed at MIT and now funded by Bill Gates. It's an implanted birth-control microchip that lasts sixteen years and "can deliver hormones into the body via an on-off switch on your mobile phone," Istvan (2014) explains; "It's not a huge jump to imagine governments seeing opportunity in using this. Many children born into poverty end up costing governments billions. ... a high percentage of those same kids will end up on the streets, in gangs, or in prison after they become adults" (Istvan, 2014). ${ }^{20}$

This is what the new urban frontier looks like when today's informational capitalists undertake a leveraged buyout of the revolutionary urban theories of the 1960s and 1970s. The social movements of Castells' (1983) City and the Grassroots are now the Networks of Outrage and Hope of "connections between networks of neural networks from human brains stimulated by signals from a communications environment through communication networks" (Castells, 2012, p. 219). Kurzweil studies brain extenders and the evolutionary hybrid of neocortex and the cloud as director of Engineering at Google, and as co-founder, with Larry Page, of an institution called Singularity University.

\footnotetext{
${ }^{20}$ Not long ago, New York City's Human Resources Administration plastered subway cars with ads designed to drive down teen pregnancy rates -- one shows a Black baby girl asking, "Honestly Mom...chances are he won't stay with you. What happens to $m e$ ?" Overall city birthrates, however, have fallen to their lowest levels since the Great Depression -- with notable exceptions in TriBeca, the Upper East Side, and Brooklyn Heights, where "stroller gridlock in gentrifying areas" and "car services that cater to 5-year-olds" proliferate along with frustration "about overcrowding in affluent school districts and rising numbers of children attending private school, making admission even more impossible." (Bellafonte, 2015).
} 
Universities, and their ecosystemic position in global city-regions, play very special roles in the evolving interface between localized urban encounters (in a Lefebvrian sense) and the "massive communications systems" (Webber, 1964) that now shape contemporary class competition on a planetary scale. University towns always seem to present themselves as places of equity, diversity, inclusion, and the limitless frontiers of idealism of students working to build new futures; but they are also sites of the exclusivity, instrumental rationality, and hamster-wheel competitions for credentials and the narrowing paths towards economic security that reflect and reinforce the inequalities of wider societies. Globally, the 'tertiary enrollment ratio' -- the "proportion of the respective age cohort enrolled in university" -- jumped from $14 \%$ to $32 \%$ in the two decades up to 2012 (Duncan, 2012, p. 4). "The World is Going to University," the cover story of The Economist proclaims, and this is where we can see furthest into the future frontiers of how gentrification is evolving, and how evolution is being gentrified. University towns and cities -- and indeed all places from which people are aspiring and striving to gain access to the cultural and economic capital symbolized by the idea of 'University' -- constitute a crucial transnational institutional interface between localized spaces of encounter and competitive processes that are speeding up and becoming more geographically expansive and dynamic. Sexton's Global Network University is only one of the more explicit brand names for a wider intensification of educational competition driven by a universalizing moral discursive momentum: who can oppose the latest strategic plan for a school to be "world class"? Who doesn't want their children to do their best, to get the best opportunities? Not long ago, the publisher James Atlas (2011) read a brochure announcing the year's winners of a prestigious study-abroad fellowship, and was astonished at the level of achievement: "Let's call this species Super Person," he suggests, and asks, "Do we have some anomalous cohort here? Achievement 
freaks on a scale we haven't seen before? Perhaps there's an evolutionary cause...." William Deresiewicz, a former English professor at Yale, describes the students of the Ivy League as an "alien species" of "bionic hamsters" (quoted in Heller, 2014, p. 68). Here at the University of British Columbia, one of the recently-admitted students is a fifteen-year old who completed high school in two years; along the way, he invented an environmentally friendly soap made from waste oil and created a handwriting recognition software application, before winning a nationwide competition for a lucrative scholarship (Chan, 2014). At the same time, one of my students too "ordinary" to win a lucrative scholarship struggled while searching for an apartment in Vancouver's turbocharged rental housing market; she arrived to one viewing only to find fifteen other students, all studying application forms pre-printed with a question that transformed the advertised monthly rent into a bidding war: "How much more are you willing to pay per month?" Vancouver has more supercars per capita than any other metropolis in North America, and has the planet's second-highest home-price-to-income ratio (behind only Hong Kong) (Ian Young, speaking on Brown, 2015). Another student tells me of her narrowly-missed traffic accident after being cut off by a young UBC student at the wheel of a Rolls Royce -- the kind of encounter that has become sufficiently frequent to inspire an anonymous blogger to create a Tumblr page with crowdsourced images of Ferraris, Maseratis, and other trophies at the "University of Beautiful Cars." ${ }^{21}$ Elsewhere in the city, one of the restaurants in the rapidlygentrifying epicenter of poverty and disinvestment sells tokens that can be given to the local homeless and panhandlers to redeem for a free sandwich; the "idealistic" entrepreneur's "quest

\footnotetext{
${ }^{21}$ Responding to the site's tagline for UBC, "Where some students drive Maseratis to school while others commute for hours," Vivien Chang (2014) provides a vivid account of the overcrowded bus route (along with a Jacob Riis update) for readers of the national news magazine Maclean's: "The buses to UBC are frequently operating over capacity, especially during peak hours, leaving students on the street corners as they pass by. Getting off the bus wet, tardy and irritable, I have often been struck by the irony of coming face to face with a luxury car and its gawking driver, and thinking, 'So this is how the other half lives."'
} 
to make an impact on the neighbourhood" is chronicled in a "docu-reality" series featured on the Oprah Winfrey Network (see Aiello, 2014). Another restaurant scrambling to survive in a ruthlessly competitive landscape of "ethical entrepreneurialism" that carefully negotiates the moral rent gap that mediates the relations between 'culinary authenticity' and hard-edged poverty (Hyde, 2014; cf. Aiello, 2014; Burnett, 2014) features a $\$ 0.50$ menu item with a promise to donate half the proceeds to local charities: "misfortune cookies." On the other side of a downtown transformed by multiple generations of urban renewal, the latest celebrity-architect trophy-tower -- Vancouver's first entry into the world-city club of the "super-prime" building classification -- includes today's trending accessory for the socially-conscious condo buyer:

"Vancouver House residents will also be connected to the global community through World Housing, which helps build houses for Third World families living in garbage dumps. For every suite purchased at Vancouver House, a new home will be donated to a family in Cambodia. Strengthening the connection, each Vancouver House resident will be able to meet the family it assisted, either on paper or online.” (Stone, 2014, p. G6).

The "one-for-one real estate gifting model” of World Housing connects Vancouver's everescalating property market -- as well as its growing community of professionals committed to the "social sustainability" and "ethical architecture" movements -- to a garbage dump outside Phnom Penh through the philanthropist Scott Neeson, a former president at Twentieth Century Fox International involved in more than 200 films over a decade (Bellet, 2014). Bjarke Ingels, the young starchitect of Vancouver House who has advised that his profession should be properly 
understood as "Worldcraft" -- turning "surreal dreams into inhabitable space" -- has gone on to submit one of the designs under consideration for Google's new headquarters campus in Mountain View, California. The plan would replace an existing patchwork of 7.5 million square feet of leased office space with a new landscape for which Google will be its own developer, creating the equivalent of four Empire State Buildings' worth of office space in large, transparent canopies that will be movable, "like furniture" (Dougherty, 2015).

Google's furniture future provides a unique perspective on the "furniture of the mind" that so fascinated Dewey in the Darwinian revolution a century ago. The Googleplex is just across the highway from the old NASA Ames Research Park, where we now find Singularity University. Part of the Singularity -- that wonderful convergence of people, creativity, and code that reminds John Sexton of Teilhard's noösphere -- involves what Marc Andreesen (2011) has described as "software eating the world," as code replaces conscious, embodied human labor. "Technology changes, and it changes more quickly than human beings change," Nick Carr (2014, p. 40) warns. "Where computers spring forward at the pace of Moore's law, our own innate abilities creep ahead with the tortoise-like tread of Darwin's law." Carr's (2014) review of the history makes it clear that those words could have been spoken by the pioneers of cybernetics (like the child prodigy who entered Tufts University at age 11 and earned a $\mathrm{Ph} . \mathrm{D}$. from Harvard at age 18, Norbert Wiener); but read those words again, and consider how each of these figures might respond: Herbert Spencer, John D. Rockefeller, Patrick Geddes, John Dewey, Robert Park, Frederick Jackson Turner, Charles Galton, Ed Glaeser, John Sexton, Richard Florida, and Ray Kurzweil. Kurzweil's "brain extenders" and "nanobots" connecting individual brains to the cloud promise to resolve the speed differential between Moore's law and Darwin's law -- like the 
"genetic surgeon" described by Sir Charles Galton Darwin back in 1955 -- creating a new cognitive Darwinism that adapts to the stepped-up pace of competition in today's survival-ofthe-fittest worlds of social Darwinism. This is the future. For only $\$ 12,000$ ( $\$ 1,000$ down) you can take the week-long Executive Program at Singularity University to learn how to adapt, compete, and survive in an urbanizing world where Silicon Valley's update of Geddes' "neotechnic order" has intensified the urbanization of social-Darwinist competitive evolution: the new planetary urban frontier.

Or you could try to get into Stanford, or Berkeley, or Harvard or MIT, or perhaps NYU's Global Network University. Compete with the best. As we consider the accelerating race between technology and education -- as humans compete on ever more planetary scales with other humans, with robots, and with code -- we get a glimpse of the future of measurement, classification, and the competitive transformation of the urban. The view from Silicon Valley is clear. There's no need to put on the Google Glass headset to see Turner's noösphere. You see it in the rage over the tech industry's turbocharged gentrification of San Francisco, and the protests over the private Google Buses taking tech workers out from the San Francisco neighborhoods they've invaded to the suburban Valley. You see it in the recombinant innovations of capital, property, creativity, and information amongst entrepreneurs, developers, and homebuyers racing to survive in their particular ecosystemic urban niches in cities around the world. You see it in every year's class of hopeful students around the world struggling to get into the very best universities, even as those universities scramble furiously to work their way up in all the various rankings. You see it in the multitudes who apply to institutions like the Global Network University, Singularity U, or a growing number of elite university divisions and franchises that 
all, taken together, bear a striking resemblance to Galton's (1910) final fantasy -- the cosmopolitan patriots of his utopian novel The Eugenic College of Kantsaywhere. Look at the cosmopolitan pioneers of the noösphere on the Singularity frontier. You can see the evolution of gentrification, and the gentrification of evolution.

\section{Acknowledgments}

I am grateful to the Editors of Urban Studies, and to SAGE for the opportunity to present a version of this paper to the Annual Conference of the Association of American Geographers in Chicago, April 2015. Thanks to Tony O’Sullivan, Ronan Paddison, Andrew Cumbers, Jon Bannister, Robert Lake, Emily Rosenman, and Pablo Mendez for valuable comments and recommendations on previous versions. I also apologize to the prominent ecological modeling specialist David P. Turner at Oregon State University, whose contemporary analysis of the noösphere (Turner, 2005) should not be confused with the target of my title -- the evolutionary environmental-determinist historian Frederick Jackson Turner; thanks to Tony O'Sullivan for the reference. 


\section{References}

Aiello, Daniela (2014). Vancouver's Downtown Eastside: An Ethnography of Restaurateurs and Neighborhood Change. MA Thesis. Burnaby, BC: Department of Geography, Simon Fraser University.

Alchian, Armen A. (1950). “Uncertainty, Evolution, and Economic Theory.” Journal of Political Economy 58(2), 211-222.

Alfasi, Nurit, and Erela Ganan (2015). "Jerusalem of (Foreign) Gold: Entrepreneurship and Pattern-Driven Policy in a Historic City.” Urban Geography 36(2), 157-180.

Allen, John, and Allan Cochrane (2007). "Beyond the Territorial Fix: Regional Assemblages, Politics, and Power." Regional Studies 42, 1161-1175.

Alonso, William (1964). Location and Land Use. Cambridge, MA: Harvard University Press.

Andreesen, Marc (2011). “Why Software is Eating the World.” Wall Street Journal, August 20.

Appiah, Kwame Anthony (1997). “Cosmopolitan Patriots.” Critical Inquiry 23(3), 617-639.

Atkinson, Rowland, and Gary Bridge, eds. (2005). Gentrification in a Global Context: The New Urban Colonialism? New York: Routledge. 
Atlantic Monthly (1864). "Review, Illustrations of Progress: A Series of Discussions with Herbert Spencer, With a Notice of Spencer's 'New System of Philosophy,' New York: D. Appleton \& Co.” Atlantic Monthly 13(80), June, 775-777.

Atlas, James (2011). “Super People.” New York Times, October 1.

Aviv, Rachel (2013). “The Imperial Presidency.” The New Yorker, September 9.

Ball, Philip (2014). "Gentrification is a Natural Evolution.” The Guardian, 19 November.

Ball, Philip (2006). "Econophysics: Culture Crash.” Nature 441, 686-688.

Baptista, Idalina (2013). "The Travels of Critiques of Neoliberalism: Urban Experiences from the “Borderlands."” Urban Geography 34(5), 590-611.

Barnes, Trevor J. (1998). “A History of Regression: Actors, Networks, Machines, and Numbers.” Environment \& Planning A 30, 203-223.

Beauregard, Robert A. (1986). “The Chaos and Complexity of Gentrification.” In Neil Smith and Peter Williams, eds., Gentrification of the City. Boston: Allen \& Unwin, 35-55.

Becker, Gary S. (1976). “Altruism, Egoism, and Genetic Fitness: Economics and Sociobiology." Journal of Economic Literature 14(2), 817-826. 
Bellafonte, Ginia (2015). “Baby Boom Among New York’s Affluent.” New York Times, April 30, MB1.

Bellett, Gerry (2014). "Ex-Film Mogul Finds Fulfillment in Dump.” Vancouver Sun, November 5, A9.

Berry, Brian J.L. (1980). “Creating Future Geographies.” Annals of the Association of American Geographers 70(4), 449-458.

Berry, Brian J.L. (1978). “Geographical Theories of Social Change.” In Brian J.L. Berry, ed., Perspectives in Geography 3: The Nature of Change in Geographical Ideas. DeKalb, IL: Northern Illinois Press, 17-35.

Big Think (2014). "We Are Big Idea Hunters." http://bigthink.com, last accessed August 16.

Binmore, Kenneth (2005). Natural Justice. Oxford: Oxford University Press.

Blaut, James (1993). The Colonizer's Model of the World. New York: Guilford Press.

Block, Robert H. (1980). "Frederick Jackson Turner and American Geography." Annals of the Association of American Geographers 70(1), 31-42. 
Brown, Jesse (2015). CanadaLand: Episode 86, Hongcouver. Available at http://canadalandshow.com/podcast/hongcouver

Buchanan, Mark (2007). The Social Atom: Why the Rich Get Richer, Cheaters Get Caught, and Your Neighbor Usually Looks Like You. New York: Bloomsbury.

Burnett, Katharine (2014). "Commodifying Poverty: Gentrification and Consumption in Vancouver's Downtown Eastside.” Urban Geography 35(2), 157-176.

Butler, Tim (2007). “For Gentrification?” Environment and Planning A 39(1), 162-181.

Buttimer, Anne (1971). Society and Milieu in the French Geographic Tradition. Chicago: Rand McNally / Association of American Geographers.

Carapezza, Kirk, and Mallory Noe-Payne (2014). “NYU’s John Sexton: Higher Education Costs." On Campus: WGBH News Higher Education Blog, 17 October. Boston: WGBH Public Broadcasting System.

Carr, Nicholas (2014). The Glass Cage: Automation and Us. New York: Norton.

Cartier, Carolyn (2015). "What's Shifting? Urban Perspectives from Two Quadrants." In Editors, "New Urban Geographies," Urban Geography 36(3), 327-339. 
Castells, Manuel (2012). Networks of Outrage and Hope: Social Movements in the Internet Age. Cambridge: Polity Press.

Castells, Manuel (1983). The City and the Grassroots. Berkeley, CA: University of California Press.

Cavell, Richard (2002). McLuhan in Space: A Cultural Geography. Toronto: University of Toronto Press.

Cayne, Bernard S., ed. (1990). The New Lexicon Webster's Encyclopedic Dictionary. New York: Lexicon Publications.

Centre on Housing Rights and Evictions (2007). Mega-Events, Olympic Games, and Housing Rights. Geneva: UN Habitat / Centre on Housing Rights and Evictions.

Centre on Housing Rights and Evictions (2006). Forced Evictions: Violations of Human Rights. Tenth Global Survey of Forced Evictions. Geneva: Centre on Housing Rights and Evictions.

Chan, Cheryl (2014). “Scholarship Boosts 15-Year-Old at UBC.” The Province, August 19, A4.

Chang, T.C. (2015). "New Uses Need Old Buildings: Gentrification Aesthetics and the Arts in Singapore." Urban Studies, forthcoming. 
Chang, Vivien (2014). “What's Behind the University of Beautiful Cars?” Maclean's, March 6.

Clark, Eric (2015). “Afterword: The Adventure of Generic Gentrification.” In Loretta Lees, Hyun Bang Shin, and Ernesto López-Morales, eds., Global Gentrifications: Uneven Development and Displacement. Bristol: Policy Press, 453-456.

Clark, Eric (2005). “The Order and Simplicity of Gentrification: A Political Challenge." In Rowland Atkinson and Gary Bridge, eds., Gentrification in a Global Context: The New Urban Colonialism. London: Routledge, 256-264.

Clark, Eric (1987). The Rent Gap and Urban Change: Case Studies in Malmö, 1860-1985. Lund: Lund University Press.

Clark, Thomas L., and Eric Clark (2012). "Participation in Evolution and Sustainability.” Transactions of the Institute of British Geographers NS37, 563-577.

Comte, Auguste (1842). Social Physics. Book VI, Course in Positive Philosophy, reprinted in Getrud Lenzer, ed. (1998). Auguste Comte and Positivism: The Essential Writings. New Brunswick, NJ: Transaction Publishers, 195-297.

Coscarelli, Joe (2014). “Spike Lee's Amazing Rant Against Gentrification: 'We Been Here!” New York Magazine, 25 February. 
Darwin, Charles (1876). "Recollections of the Development of My Mind and Character." In James A. Secord, ed., Charles Darwin: Evolutionary Writings. Oxford: Oxford University Press, 355-425.

Darwin, Sir Charles Galton (1956). “The Time Scale in Human Affairs.” In William L. Thomas, ed., Man's Role in Changing the Face of the Earth. Chicago: University of Chicago Press, 963-969.

Davidson, Mark, and Loretta Lees (2010). 'New-Build Gentrification: Its Histories, Trajectories, and Critical Geographies.” Population, Space, and Place 16, 395-411.

Dewey, John (1939). “Socializing Intelligence." Excerpts from Liberalism and Social Action (1929) and Individualism Old and New (1930), reprinted in John Dewey, Intelligence in the Modern World. New York: Random House / Modern Library, 455-466.

Dewey, John (1920). Reconstruction in Philosophy. New York: Henry Holt.

Dewey, John (1918). "Internal Social Reorganization After the War.” Journal of Race Development, April, reprinted in John Dewey (1939), Intelligence in the Modern World. New York: Random House / Modern Library, 405-433.

Dewey, John (1909). “The Influence of Darwin on Philosophy.” Popular Science Monthly 75, 90-98. 
Dewey, John (1904). “The Philosophical Work of Herbert Spencer.” The Philosophical Review, reprinted in Joseph Ratner, ed. (1929) Characters and Events: Popular Essays in Social and Political Philosophy by John Dewey. New York: Henry Holt \& Company, 45-62.

Dopfer, Kurt (2005). “Evolutionary Economics: A Theoretical Framework.” In Kurt Dopfer, ed., The Evolutionary Foundations of Economics. Cambridge: Cambridge University Press, 355.

Dorfmann, Jessica (2015). "New Wealth Seeks a 'Home': The Rise of the Hedge City." Harvard International Review 36(3).

Dougherty, Conor (2014). “Google Unveils Plan for New Corporate Campus.” New York Times, 27 February.

Duncan, Emma (2015). "Excellence v. Equity: Special Report on Universities.” The Economist, 28 March, 19 pp.

Durgan, Edward (2013). Resistance and Complexity: Solutions to Urban Crises of Homelessness and Psychopathology Through Psychiatry, Architecture, and Philosophy. Ph.D. Thesis. Vancouver: Interdisciplinary Studies, The University of British Columbia.

Dyson, George (2012). Turing's Cathedral: The Origins of the Digital Universe. New York: Vintage. 
Ely, Richard T. (1884). The Past and the Present of Political Economy. Johns Hopkins University Studies in Historical and Political Science, Vol. II. Baltimore: Johns Hopkins University.

Entrikin, J. Nicholas (1980). “Robert Park’s Human Ecology and Human Geography.” Annals of the Association of American Geographers 70(1), 43-58.

Fernandes, Leela (2006). India's New Middle Class: Democratic Politics in an Era of Economic Reform. Minneapolis: University of Minnesota Press.

Flatley, Joseph L. (2015). “In the Basement with Transhumanism's DIY Cyberpunks.” The Daily Dot, April 26.

Florida, Richard (2014). “Foreword.” In Paul L. Knox, ed., Atlas of Cities. Princeton: Princeton University Press, 8-9.

Florida, Richard (2006). "The Flight of the Creative Class: The New Global Competition for Talent." Liberal Education 92(3), 22-29.

Florida, Richard (2003). "Cities and the Creative Class." City \& Community 2(1), 3-19. 
Florida, Richard, and Charlotta Mellander (2014). "Geographical Psychology: Exploring the Interaction of Environment and Behavior." Washington, DC: American Psychological Association, 261-274.

Friedman, Milton (1953). Essays in Positive Economics. Chicago: University of Chicago Press.

Galton, Sir Francis (1910). The Eugenic College of Kantsaywhere. London: University College London.

Galton, Francis (1869). Hereditary Genius: An Inquiry Into Its Laws and Consequences. London: Richard Clay and Sons.

Garcia, Justin R., and Gad Saad (2008). "Evolutionary Neuromarketing: Darwinizing the Neuroimaging Paradigm for Consumer Research.” Journal of Consumer Behavior 7, 397-414.

García-Ajofrin, Lola (2014). "Es el puto síndrome de Christóbal Colón. Nosotros hicimos Harlem, ahora nosechan.” El Confidential, June 20.

Geddes, Patrick (1915). Cities in Evolution. London: Williams \& Norgate.

Ghent, William J. (1902). Our Benevolent Feudalism. New York: MacMillan. 
Gibson-Graham, J.K., Stephen A. Resnick, and Richard D. Wolff, eds. (2000). Class and its Others. Minneapolis: University of Minnesota Press.

Glaeser, Edward (2011). Triumph of the City: How Our Greatest Invention Makes Us Richer, Smarter, Greener, Healthier, and Happier. New York: Penguin.

Glass, Ruth (1964). “Introduction.” In Centre for Urban Studies, ed., London: Aspects of Change. London: MacGibbon \& Kee, xii-xlii.

Hamnett, Chris (1991). "The Blind Men and the Elephant: The Explanation of Gentrification." Transactions of the Institute of British Geographers, NS 16(2), 173-189.

Harris, Andrew (2008). "From London to Mumbai and Back Again: Gentrification and Public Policy in Comparative Perspective.” Urban Studies 45(12), 2407-2428.

Harvey, David (2014). Seventeen Contradictions and the End of Capitalism. Oxford: Oxford University Press.

Harvey, David (1989). The Urban Experience. Baltimore: Johns Hopkins University Press.

Harvey, David (1982). The Limits to Capital. Chicago: University of Chicago Press. 
Harvey, David (1978). “On Countering the Marxian Myth -- Chicago-Style.” Comparative Urban Research, reprinted in Spaces of Capital: Towards a Critical Geography. New York: Routledge, 68-89.

Harvey, David (1973). Social Justice and the City. London: Edward Arnold.

Heller, Nathan (2014). "Poison Ivy: Are Elite Colleges Bad for the Soul?" The New Yorker, September 1, 68-72.

Hodgson, Geoffrey M. (2009). “Introduction.” In Geoffrey M. Hodgson, ed., Darwinism and Economics. Cheltenham: Edward Elgar, xi-xxxvi.

Hodgson, Geoffrey (2003a). "Darwinism and Institutional Economics.” Journal of Economic Issues 37(1), 85-97.

Hodgson, Geoffrey (2003b). “Preface.” In John Laurent, ed., Evolutionary Economics and Human Nature. Cheltenham, UK: Edward Elgar, ix-xiii.

Hofstadter, Richard (1944). Social Darwinism in American Thought, 1860-1915. Philadelphia: University of Pennsylvania Press. 
Hoyt, Homer (1933). One Hundred Years of Land Values in Chicago: The Relationship of the Growth of Chicago to the Rise in its Land Values, 1830-1933. Chicago: University of Chicago Press.

Hyde, Zachary (2014). “Omnivorous Gentrification: Restaurant Reviews and Neighborhood Change in the Downtown Eastside of Vancouver." City \& Community 13(4), 341-359.

Iossifova, Deljana (2009). "Negotiating Livelihoods in a City of Difference: Narratives of Gentrification in Shanghai.” Critical Planning 16(2), 99-116.

Istvan, Zoltan (2014). "It's Time to Consider Restricting Human Breeding." Wired UK, August 14.

Keynes, John Maynard (1926). The End of Laissez-Faire. London: L.\&V. Woolf.

Knopp, Larry (1997). "Gentrification and Gay Neighborhood Formation in New Orleans: A Case Study.” In Amy Gluckman and Betsy Reed, eds., Homo Economics: Capitalism, Community, and Lesbian and Gay Life. New York: Routledge, 45-63.

Krueckeberg, Donald A. (1995). “The Difficult Character of Property: To Whom Do Things Belong?" Journal of the American Planning Association 61(3), 301-309. 
Kurzweil, Ray (2005). The Singularity is Near: When Humans Transcend Biology. London:

Penguin.

Lambert, Christine, and Martin Boddy (2002). Transforming the City: Post-Recession Gentrification and Re-urbanisation. ESRC Centre for Neighbourhood Research.

Lanier, Jaron (2013). Who Owns the Future? New York: Norton.

Lanier, Jaron (2010). You Are Not a Gadget: A Manifesto. New York: Knopf.

Lee-Young, Joanne (2015). “Buyer of \$51.8M Home Was a Duck Farmer.” Vancouver Sun, 18 March, A6.

Lees, Loretta (2012). “The Geography of Gentrification: Thinking Through Comparative Urbanism.” Progress in Human Geography 36(2), 155-171.

Lees, Loretta, Hyun Bang Shin, and Ernesto López-Morales (2015a). “Conclusion: Global Gentrification.” In Loretta Lees, Hyun Bang Shin, and Ernesto López-Morales, eds., Global Gentrifications: Uneven Development and Displacement. Bristol: Policy Press, 441-452.

Lees, Loretta, Hyun Bang Shin, and Ernesto López-Morales (2015b). “Introduction: ‘Gentrification'--A Global Urban Process?” In Loretta Lees, Hyun Bang Shin, and Ernesto 
López-Morales, eds., Global Gentrifications: Uneven Development and Displacement. Bristol: Policy Press, 1-18.

Lees, Loretta, Tom Slater, and Elvin Wyly, eds. (2010). The Gentrification Reader. London: Routledge.

Lefebvre, Henri (1970). The Urban Revolution. 2003 translation, Robert Bononno. Minneapolis: University of Minnesota Press.

Ley, David (2010). Millionaire Migrants: Trans-Pacific Life Lines. Chichester: Wiley.

Ley, David (1996). The New Middle Class and the Remaking of the Central City. Oxford: Oxford University Press.

Ley, David (1987). "Reply: The Rent Gap Revisited." Annals of the Association of American Geographers 77(3), 465-468.

Ley, David, and Sin Yih Teo (2013). “Gentrification in Hong Kong? Epistemology vs. Ontology.” International Journal of Urban and Regional Research 38(4), 1286-1303.

Lowry, Ira S. (1960). "Filtering and Housing Standards: A Conceptual Analysis.” Land Economics 36(4), 362-370. 
MacKenzie, Donald (1976). “Eugenics in Britain.” Social Studies of Science 6(3/4), 499-532.

Maloutas, Thomas (2011). “Contextual Diversity in Gentrification Research.” Critical Sociology 38(1), 33-48.

MarketWatch (2015). "LinkedIn Wants to Map the Global Economy.” MarketWatch, April 9.

Martindale, Don (1958). "Prefatory Remarks: The Theory of the City." In Max Weber, The City, translated and edited by Don Martindale and Gertrud Neuwirth. Glencoe, IL: The Free Press, 9-60.

Mazur, Paul, and Jane Perlez (2014). "Gregarious and Direct: China's Web Doorkeeper." New York Times, December 1.

McCann, Eugene, Ananya Roy, and Kevin Ward (2013). “Urban Pulse: Assembling/Worlding Cities.” Urban Geography 34(5), 581-589.

Merrifield, Andy (2013). “The Urban Question Under Planetary Urbanization.” International Journal of Urban and Regional Research 37(3), 909-922.

Metzger, John T. (2000). "Planned Abandonment: The Neighborhood Life-Cycle Theory and National Urban Policy." Housing Policy Debate 11(1), 7-40. 
Mirowsky, Philip (2005). "How Positivism Made a Pact with the Postwar Social Sciences in the United States.” In George Steinmetz, ed., The Politics of Method in the Human Sciences:

Positivism and its Epistemological Others. Durham, NC: Duke University Press, 142-172.

Mooney, Chris (2015). “Pope Dares to Side with Science.” Washington Post, January 3, B5.

Moulier-Boutang, Yann (2012). Cognitive Capitalism. Cambridge: Polity.

Mozur, Paul (2014). “Warm West Coast Reception for China’s Web Czar (Chillier in Washington)." New York Times, December 8.

Muth, Richard (1969). Cities and Housing. Chicago: University of Chicago Press.

New York Times (2015). “\$100.4 Million Sale at One67.” New York Times, 23 January.

Nguyen, Tina (2014). "NY Times to Reporters: Please Stop Comparing Everything to Brooklyn.” Mediaite.com, 18 November.

Norton, Bernard J. (1978). "Karl Pearson and Statistics: The Social Origins of Scientific Innovation.” Social Studies of Science 8(1), 3-35.

O’Connor, Clare (2014). “Amazon's Wholesale Slaughter.” Forbes, May 26, 88-94. 
Ong, Aihwa (2011). "Worlding Cities, or the Art of Being Global.” In Ananya Roy and Aihwa Ong, eds., Worlding Cities: Asian Experiments and the Art of Being Global. Chichester: WileyBlackwell, 1-26.

Parekh, Trushna (2015). "They Want to Live in the Tremé, but They Want it for Their Ways of Living." Urban Geography 36(2), 201-220.

Park, Robert E. (1925). "The City: Suggestions for the Investigation of Human Behavior in the Urban Environment.” In Robert E. Park, Ernest W. Burgess, and Roderick D. McKenzie, The City. Chicago: University of Chicago Press, 1-46.

Park, Robert E. (1921). “The Social Organism and the Collective Mind.” American Journal of Sociology 27(1), 1-21.

Rees, Peter Wynne (2015). "London Needs Homes, Not Towers of 'Safe-Deposit Boxes."” The Guardian, January 25.

Ren, Julie (2015). “Gentrification in China?” In Loretta Lees, Hyun Bang Shin, and Ernesto López-Morales, eds., Global Gentrifications: Uneven Development and Displacement. Bristol: Policy Press, 329-347.

Rescher, Nicholas (2005). Realism and Pragmatic Epistemology. Pittsburgh: University of Pittsburgh Press. 
Rescher, Nicholas (1977). Methodological Pragmatism: A Systems-Theoretic Approach to the Theory of Knowledge. Oxford: Basil Blackwell.

Richtel, Matt (2015). “For Tech Titans, Sharing Has Its Limits." New York Times, March 14.

Robinson, Jennifer (2006). Ordinary Cities: Between Modernity and Development. New York: Oxford.

Robson, Arthur (2002). "Evolution and Human Nature." Journal of Economic Perspectives 16(2), 89-106.

Rose, Damaris (1984). "Rethinking Gentrification: Beyond the Uneven Development of Marxist Urban Theory.” Environment and Planning D, Society and Space 1, 47-74.

Roy, Ananya (2011). “Postcolonial Urbanism: Speed, Hysteria, Mass Dreams.” In Ananya Roy and Aihwa Ong, eds., Worlding Cities: Asian Experiments and the Art of Being Global. Chichester: Wiley-Blackwell, 307-335.

Saddy, Guy (2015). "If This is Our New Urban Dream, is the West Side Sleeping Through it?" Vancouver Magazine, April 46-53.

Schill, Michael, and Richard Nathan (1983). Revitalizing America's Cities: Neighborhood Reinvestment and Displacement. Albany, NY: State University of New York Press. 
Scott, Allen J. (2014). "Beyond the Creative City: Cognitive-Cultural Capitalism and the New Urbanism.” Regional Studies 48(4), 565-578.

Scott, Allen J. (2011a). “A World in Emergence: Notes Toward a Resynthesis of UrbanEconomic Geography for the 21st Century." Urban Geography 32(6), 845-870.

Scott, Allen J. (2011b). "Emerging Cities of the Third Wave." City 15(3/4), 289-321.

Scott, Allen J. (2007). "Capitalism and Urbanization in a New Key? The Cognitive-Cultural Dimension.” Social Forces 85(4), 1465-1482.

Secord, James A. (2008). “Introduction.” In James A. Secord, ed., Charles Darwin: Evolutionary Writings. Oxford: Oxford University Press, vii-xxxvii.

Sexton, John (2010). Global Network University Reflection. December 21. New York: Office of the President, New York University.

Sexton, John (2008). “NYU's Global Future.” Speech distributed on Big Think, http://bigthink.com, recorded may 29.

SFU Public Square (2014). Innovation: The Shock of the Possible. Vancouver/Burnaby: Simon Fraser University. 
Shao, Qin (2013). Shanghai Gone: Domicide and Defiance in a Chinese Megacity. Lanham, MD: Rowman \& Littlefield.

Shin, Hyun Bang (2012). Looking Back and Ahead: Lessons from the 2008 Beijing Olympic Games. London: London School of Economics.

Slater, Tom (2015). "Planetary Rent Gaps.” Antipode, forthcoming.

Slater, Tom (2014). "There is Nothing Natural About Gentrification." New Left Project, 24 November.

Slater, Tom (2009). "The Eviction of Critical Perspectives from Gentrification Research." International Journal of Urban and Regional Research 30(4), 737-757.

Smith, Neil (2010). “The Evolution of Gentrification.” In J. Berg, T. Kaminer, M.

Schoonderbeek \& J. Zonneveld, eds., Houses in Transformation: Interventions in European Gentrification. Rotterdam: NAi Publishers, 15-26.

Smith, Neil (2009). “The Revolutionary Imperative.” Antipode 41(S1) 50-65.

Smith, Neil (2003). American Empire: Roosevelt's Geographer and the Prelude to Globalization. Berkeley: University of California Press. 
Smith, Neil (2002). "New Globalism, New Urbanism: Gentrification as Global Urban Strategy." Antipode 34(3), 427-450.

Smith, Neil (1996). The New Urban Frontier: Gentrification and the Revanchist City. New York: Routledge.

Smith, Neil (1987). "Commentary: Gentrification and the Rent Gap." Annals of the Association of American Geographers 77(3), 462-465.

Smith, Neil (1979). "Toward a Theory of Gentrification: A Back to the City Movement by Capital, Not People." Journal of the American Planning Association 45(4), 538-548.

Smith, Neil (1977). The Return from the Suburbs and the Structuring of Urban Space: State Involvement in Society Hill, Philadelphia. St. Andrews, Scotland: Department of Geography, University of St. Andrews.

Stegman, Michael A. (1969). “Accessibility and Models of Residential Location.” Journal of the American Institute of Planners 35(1), 22-29.

Stone, Felicity (2014). "Vancouver House Tower a 'Living Sculpture.” Vancouver Sun, September 13, G4, G6. 
Stone, Madeline (2015). "Silicon Valley CEOs Just Want a Little Privacy. \$100 Million and 750 Acres of It.” Business Insider, via Slate, May 18.

Surowiecki, James (2014). "Real Estate Goes Global.” New Yorker, May 26.

Taylor, Monique (2003). Harlem: Between Heaven and Hell. Minneapolis: University of Minnesota Press.

Teilhard de Chardin, Pierre (1964). The Future of Man, translated by Norman Denny. New York: Doubleday.

Teilhard de Chardin, Pierre (1956). "The Antiquity and World Expansion of Human Culture." In William L. Thomas, ed., Man's Role in Changing the Face of the Earth. Chicago: University of Chicago Press, 103-112.

Teilhard de Chardin, Pierre (1947). "The Formation of the Noosphere." In The Future of Man, translated by Norman Denny. New York: Doubleday, 149-178.

Todd, Douglas (2015). “Ritzy Neighborhood Where Many are 'Poor.” Vancouver Sun, June $15, \mathrm{~A} 1, \mathrm{~A} 5$.

Turner, David P. (2005). "Thinking at the Global Scale.” Global Ecology and Biogeography 14, 505-508. 
Turner, Frederick Jackson (1893). “The Significance of the Frontier in American History.” Annual Report of the American Historical Association, 199-227.

Webber, Melvin M. (1964). “The Urban Place and the Nonplace Urban Realm.” In Melvin M.

Webber, John W. Dyckman, Donald L. Foley, Albert Z. Guttenberg, William L.C. Wheaton, and Catherine Bauer Wurster, Explorations into Urban Structure. Philadelphia: University of Pennsylvania Press, 79-153.

Wheaton, William (1977). "Income and Urban Residence: An Analysis of Consumer Demand for Location." American Economic Review 67, 620-631.

White, Morton, and White, Lucia (1962). The Intellectual Versus the City: From Thomas Jefferson to Frank Lloyd Wright. Cambridge: Harvard University Press / MIT Press.

Yaffe, Barbara (2015). "Real Estate Pandemonium.” Vancouver Sun, May 26, D2.

Young, Ian (2015). “Something is Grotesquely Wrong with Vancouver's Housing Market, and the Time for Denialism is Over." South China Morning Post, May 21.

Zhao, Yong (2009). "Comments on the Common Core Standards Initiative." AASA Journal of Scholarship and Practice 6(3), 46-54. 